\title{
Chemotypes and antibacterial activities of Inula viscosa essential oils from Algeria
}

\author{
ABDELKADER OUNOUGHI ${ }^{1,2}$, MESSAOUD RAMDANI ${ }^{1, \bullet}$, TAKIA LOGRADA ${ }^{1}$, PIERRE CHALARD $^{3}$, \\ GILLES FIGUEREDO ${ }^{4}$ \\ ${ }^{1}$ Laboratory of Natural Resource Valorisation, SNV Faculty, Setif 1 University. 19000 Setif, Algeria. `email: ramdanimessaoud@univ-setif.dz; \\ ramdanimessaoud@yahoo.com \\ ${ }^{2}$ Université Larbi Ben M'Hidi, Faculté des Sciences Exactes et de la Nature et de la Vie. 04000 Oum El Bouaghi, Algeria \\ ${ }^{3}$ Université Clermont Auvergne, CNRS, SIGMA Clermont, ICCF. F-63000 Clermont-Ferrand, France \\ ${ }^{4}$ LEXVA Analytique. 460 Rue Du Montant, 63110 Beaumont, France
}

Manuscript received: 7 January 2020. Revision accepted: 20 March 2020.

\begin{abstract}
Ounoughi A, Ramdani M, Lograda T, Chalard P, Figueredo G. 2020. Chemotypes and antibacterial activities of Inula viscosa essential oils from Algeria. Biodiversitas 21: 1504-1517. The aim of this work is to investigate the chemical composition and the antibacterial activities of the essential oils from Inula viscosa (L.) Aiton. Samples were collected in the flowering stage, from different localities in Algeria. The aerial parts of $I$. viscosa were submitted to a hydro distillation. The chemical composition of the essential oil was analyzed by GC and GC/MS. The antibacterial activity of the essential oils was evaluated using the disc diffusion method against fifteen bacterial species. Fifty-eight compounds representing $98.93 \pm 2.03 \%$ of the total oil was identified in $I$. viscosa. It was found that the chemical composition was dominated by the presence of the following major products: polygodial $(19.8 \pm 16.97 \%)$, phytol $(12.3 \pm 9.77 \%)$, fokienol $(6.01 \pm 3.43 \%)$, intermedeol neo $(5.09 \pm 2.38 \%)$, caryophyllene oxide $(4.91 \pm 3.03 \%)$, nerolidol-Z $(4.46$ $\pm 5.46 \%)$, nerolidol-E $(4.24 \pm 8.07 \%)$ and $\alpha$-ionone iso methyl-E $(3.72 \pm 2.26 \%)$. The essential oil of $I$. viscosa has moderate activity against the bacteria tested. In contrast, the Escherichia coli ATCC 25922, Pseudomonon syringae ATCC 53543 and Enterococcus faecalis ATCC 49452 strains are resistant to I. viscosa essential oils. The phytochemical study of $I$. viscosa showed that it is rich in terpene compounds, with polygodial and phytol as major components. Three distinct chemotypes are highlighted. The (PolygodialIntermedeol-neo-Phytol) chemotype of Salah Bey population and two chemotypes with Fokinol-polygodial and Fokinol-phytol. Moderate antibacterial activities of essential oils against the bacteria tested were found.
\end{abstract}

Keywords: Algeria, antibacterial activity, chemotypes, essential oil, Inula viscosa

\section{INTRODUCTION}

Inula viscosa (L.) Aiton (Asteraceae) is a herbaceous perennial plant widely spread in the Mediterranean area. The taxonomic revision of the Dittrichia genus showed that I. viscosa is a synonym of the accepted name Dittrichia viscosa (L.) Greuter (Brullo and De Marco 2000; Parolin et al. 2014). This taxonomic change is confirmed in the online "The Plant List" database. It should also be noted that the name I. viscosa continues to appear in the literature (Kattouf et al. 2009; Talib et al. 2012; Andolfi et al. 2013; Haoui et al. 2015; Prisa 2019).

Inula viscosa is the most frequently cited among the species of the Inula genus, for its vast ethnopharmacological applications (Lev and Amar 2000; Zhao et al. 2006; Merghoub et al. 2009; Al-Qudah et al. 2010; Rajkumar 2012; Amin et al. 2013; Belayachi et al. 2013; Bouyahya et al. 2018; Ozkan et al. 2019). It is used to treat a wide range of disorders, primarily respiratory, gastrointestinal, inflammatory, dermatological, cancer and microbial diseases (Seca et al. 2014; Rhimi et al. 2017, 2018).

Inula viscosa has several biological activities such as: antipyretic and antiseptic (Lauro and Rolih 1990), antifungal (Cohen et al. 2002; Cafarchia et al. 2002;
Franco-Mican et al. 2008; Bssaibiss et al. 2009; Al-Masri et al. 2015; Rhimi et al. 2017, 2018; Sriti Eljazi et al. 2018; Mohti et al. 2019; Gharred et al. 2019), antimicrobial (Bssaibiss et al. 2009; Larbi et al. 2016; Rhimi et al. 2017, 2018; Aissa et al. 2019), anti-ulcerogenic (Alkofahi 1999), antioxidant (Schinella et al. 2002; Benseguini-Tounsi 2001; Remli 2013; Chahmi et al. 2015; Sriti Eljazi et al. 2018; Mohti et al. 2019; Gharred et al. 2019), antiviral (Bensassi et al. 2008), anti-tumoral (Rozenblat et al. 2008; Isil et al. 2018; Bar-Shalom et al. 2019; Hepokur et al. 2019), antimalaria (Akkawi et al. 2014), hypolipidemic (Zeggwagh et al. 2006) and anti-tyrosinase (Aissa et al. 2019). Inula's essential oils are also used in the food industry to increase the shelf life of a large number of food products, particularly fats (Boumaza 2011).

The essential oils chemical composition of I. viscosa growing in different countries have been investigated; in Island (Pistelli et al. 2018), in Portugal (Miguel et al. 2008); in Spain (Camacho et al. 2000; Blanc et al. 2006); in France (Blanc et al. 2006); in Italy (De Laurentis et al. 2002; Marongiu et al. 2003); in Turkey (Blanc et al. 2006; Sevindik et al. 2017); in Jordan (Al-Qudah et al. 2010); in Syria (Nasser et al. 2014; Alalan et al. 2015), in Lebanon (Assi et al. 2010) in Tunisia (Sriti Eljazi et al. 2018; Aissa et al. 2019) and in Algeria (Madani et al. 2014; Boudouda 
et al. 2014; Haoui et al. 2015) (Table 1). $\beta$-caryophyllene, tricosane, and isocostic acid characterized the populations of Algeria (Boudouda et al. 2014; Madani et al. 2014). The populations of Italy are characterized by 12-carboxy eudesma-3-11 (13)-diene (De Laurentis et al. 2002). The populations of Island are characterized by 10-epi- $\gamma$ eudesmol, $\alpha$-eudesmol, $\beta$-caryophyllene and limonene (Pistelli et al. 2018). The populations of France and Spain contain fokienol, nerolidol-(E) and $\alpha$-eudesm-6-en-4-ol (Camacho et al. 2000; Blanc et al. 2006). In Italy, the oil of this species is composed of globulol, valerianol and caryophyllene oxide (Chiarlo 1968; De Laurentis et al. 2002; Marongiu et al. 2003); in Turkey, it is composed of borneol, bornyl acetate and iso-bornyl acetate (Perez et al. 1996). I. viscosa from Syria is rich in 11-hydroxy-6ememopheryl (7)-9-(10)-dien-8-one, veridiflorol, cedr-8en-13-ol, caryophyllene oxide, $\beta$-selinene, terpineol and $\beta$ bisabolene (Hwija et al. 2018).

The essential oil from Tunisia populations are characterized by the neryle isovalerate-Z, 1,10-di-epi- cubenol and 2,5-dimethoxy-p-cymene (Aissa et al. 2019). The study by Gharred et al. (2019) showed that the chemical composition of the essential oils from different parts of the plant was variable; the flowers contain nerolidol-E, while the leaves were characterized by caryophyllene oxide, isolongifolan-7- $\alpha$-ol and $\alpha$-eudesmol.

In another study, the essential oil of I. viscosa was tested against Listeria monocytogenes which showed high resistance (Silva et al. 2005). In contrast, the essential oil showed an inhibitory effect against E. coli, K. pneumoniae, L. innocua, S. Aureus, P. aeruginosa strains (Kheyar et al. 2014; Chebouti-Meziou 2016). Enterobacter sp., Bacillus thuringiensis, Micrococcus sp. and Aspergillus niger and Candida albicans strains, were sensitive to I. viscosa oils (Chebouti-Meziou 2016).

The aim of this study is to identify the chemical composition of I. viscosa essential oils by GC/MS analysis, to compare the results with the data reported in the literature and to the geographical distribution of chemotypes in Algeria.

Table 1. Chemical composition of Inula viscosa essential oil from literature

\begin{tabular}{|c|c|c|c|c|c|c|c|c|c|c|c|c|c|c|c|c|c|}
\hline Localities & 秀 & 莺 & 栉 & 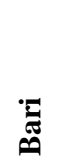 & 䒿 & 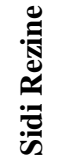 & 莺 & 莡 & 节 & $\begin{array}{l}\text { है } \\
\text { के }\end{array}$ & 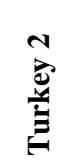 & & 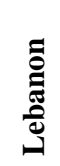 & 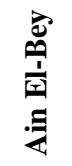 & 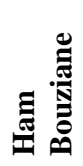 & 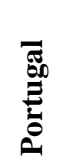 & \\
\hline References * & $\mathbf{A}$ & \multicolumn{4}{|c|}{ B } & $\mathbf{C}$ & D & $\mathbf{E}$ & $\mathbf{F}$ & $\mathbf{G}$ & $\mathbf{H}$ & I & $\mathbf{J}$ & \multicolumn{2}{|c|}{$\mathbf{K}$} & $\mathbf{L}$ & $\mathbf{M}$ \\
\hline Fokienol & 0.0 & 0.0 & 0.0 & 0.0 & 0.0 & 3.4 & 0.0 & 0.0 & 21 & 39 & 0.0 & 30 & 0.0 & 4.4 & 7.2 & 0.0 & 0.0 \\
\hline Linolenic acid & 0.0 & 0.0 & 3.0 & 0.0 & 3.8 & 7.8 & 0.0 & 0.0 & 0.0 & 0.0 & 0.0 & 0.0 & 0.0 & 3.1 & 9.1 & 0.0 & 0.0 \\
\hline Pentacosane & 7.1 & 0.0 & 0.0 & 0.0 & 0.0 & 5.4 & 0.0 & 0.0 & 0.0 & 0.0 & 0.3 & 0.0 & 0.0 & 2.0 & 0.4 & 0.0 & 0.0 \\
\hline Heptacosane & 0.0 & 0.0 & 0.0 & 0.0 & 0.0 & 4.8 & 0.0 & 0.0 & 0.0 & 0.0 & 0.0 & 0.0 & 0.0 & 2.3 & 1.9 & 0.0 & 0.0 \\
\hline Nerolidol B & 15.7 & 0.0 & 0.0 & 0.0 & 0.0 & 0.0 & 0.0 & 0.0 & 0.0 & 7.7 & 0.0 & 0.0 & 0.0 & 0.0 & 0.0 & 0.0 & 0.0 \\
\hline Caryophyllene Oxide & 3.8 & 2.6 & 0.6 & 1.3 & 2.2 & 0.2 & 1.5 & 1.9 & 2.5 & 0.0 & 3.4 & 2.6 & 2.2 & 5.5 & 0.1 & 0.0 & 8.0 \\
\hline Farnesene-E epoxide & 22.4 & 0.0 & 0.0 & 0.0 & 0.0 & 0.0 & 0.0 & 0.0 & 0.0 & 0.0 & 0.0 & 0.0 & 0.0 & 0.0 & 0.0 & 0.0 & 0.0 \\
\hline Sellin-6-En-4-ol & 2.2 & 3.3 & 1.4 & 2.1 & 2.0 & 0.0 & 0.0 & 0.0 & 1.6 & 0.0 & 0.0 & 0.0 & 0.0 & 0.0 & 0.0 & 0.0 & 0.0 \\
\hline Octadecanoic Acid & 11.5 & 0.0 & 0.0 & 0.0 & 0.0 & 0.0 & 0.0 & 0.0 & 0.0 & 0.0 & 0.0 & 0.0 & 0.0 & 0.0 & 0.0 & 0.0 & 0.0 \\
\hline Cineol-1-8 & 0.0 & 9.6 & 0.3 & 2.3 & 2.3 & 0.0 & 0.0 & 1.9 & 0.0 & 0.0 & 0.0 & 0.0 & 0.0 & 0.0 & 0.0 & 0.0 & 0.0 \\
\hline$\alpha$-Terpineol & 0.0 & 3.1 & 3.9 & 2.6 & 1.7 & 0.0 & 0.1 & 0.0 & 0.0 & 0.0 & 0.0 & 0.0 & 0.0 & 0.0 & 0.0 & 0.0 & 0.0 \\
\hline B-Caryoph & & 1.7 & 1.0 & 1.0 & 1.9 & 0.0 & 0.0 & 1.3 & 0.0 & 0.0 & 0.0 & 1.5 & 0.0 & 25 & 9.6 & 0.0 & 0.0 \\
\hline 4 cid & & 5.1 & 0.9 & 1.8 & 2. & 0.0 & 0.0 & 0 . & 0.0 & 0 & .0 & 0 & 0.0 & 0.0 & 0.0 & 0.0 & .0 \\
\hline $11(13) d$ & 0.0 & 20 & 42 & 48 & 27 & 29 & 0.0 & & 0.0 & 0.0 & & & 0.0 & .0 & 0.0 & 0.0 & .0 \\
\hline Tricosane & 0.0 & 4.6 & 0.5 & 0.7 & 1.0 & 0.0 & 0.0 & 0.0 & 0.0 & 0.0 & 0.0 & 0.0 & 0.0 & 0.0 & 1.0 & 0.0 & 0.0 \\
\hline Isocostic acid & 0.0 & 0.0 & 0.0 & 0.0 & 0.0 & 0.0 & 0.0 & 0.0 & 0.0 & 0.0 & 0.0 & 0.0 & 0.0 & 10 & 25 & 59 & 0.0 \\
\hline Borneol & 0.0 & 0.0 & 0.0 & 0.0 & 0.0 & 0.0 & 25 & 1.7 & 0.0 & 0.0 & 0.0 & 0.0 & 0.0 & 1.6 & 0.0 & 0.0 & 0.0 \\
\hline Bornyl acetate & 0.0 & 0.0 & 0.0 & 0.0 & 0.0 & 0.0 & 20 & 0.0 & 0.0 & 0.0 & 0.0 & 0.0 & 0.0 & 0.0 & 0.0 & 0.0 & 0.0 \\
\hline lsobornyl acetate & 0.0 & 0.0 & 0.0 & 0.0 & 0.0 & 0.0 & 23 & 0.0 & 0.0 & 0.0 & 0.0 & 0.0 & 0.0 & 0.0 & 0.0 & 0.0 & 0.0 \\
\hline Eugenol & 0.0 & 0.0 & 7.3 & 4.0 & 1.2 & 0.0 & 0.0 & 2.7 & 0.0 & 0.0 & 0.0 & 0.0 & 0.0 & 0.0 & 0.0 & 0.0 & 0.0 \\
\hline Intermedeol neo & 0.0 & 0.0 & 0.0 & 0.0 & 0.0 & 0.0 & 0.0 & 0.0 & 0.0 & 0.0 & 0.0 & 0.0 & 0.0 & 6.4 & 7.5 & 0.0 & 0.0 \\
\hline 2,4-dioxo-3-methyl-6-isopropyl & 0.0 & 0.0 & 0.0 & 0.0 & 0.0 & 0.0 & 0.0 & 0.0 & 0.0 & 0.0 & 29 & 0.0 & 0.0 & 0.0 & 0.0 & 0.0 & 0.0 \\
\hline Eudesma-5,11 (13)-dien-8,12- & 0.0 & 0.0 & 0.0 & 0.0 & 0.0 & 0.0 & 0.0 & 0.0 & 0.0 & 0.0 & 25 & 0.0 & 0.0 & 0.0 & 0.0 & 0.0 & 0.0 \\
\hline Bicyclo esquiphellandrene epi & 0.0 & 0.0 & 0.0 & 0.0 & 0.0 & 0.0 & 0.0 & 0.0 & 0.0 & 0.0 & 0.0 & 0.0 & 17 & 0.0 & 0.0 & 0.0 & 0.0 \\
\hline Cadinol & 0.0 & 0.0 & 0.0 & 0.0 & 0.0 & 0.0 & 0.0 & 0.0 & 0.0 & 0.0 & 0.0 & 0.0 & 0.0 & 0.0 & 0.0 & 6.3 & 0.0 \\
\hline Globulol & 0.0 & 0.0 & 0.0 & 0.0 & 0.0 & 0.0 & 0.0 & 0.0 & 0.0 & 0.0 & 0.0 & 1.8 & 4.1 & 0.0 & 0.0 & 0.0 & 17 \\
\hline Nerolidol-E & 0.0 & 6.9 & 3.4 & 2.4 & 2.9 & 0.0 & 1.5 & 1.1 & 8.6 & 0.0 & 0.0 & 20 & 0.0 & 0.0 & 0.1 & 1.1 & 1.9 \\
\hline Valerianol & 0.0 & 0.0 & 0.0 & 0.0 & 0.0 & 0.0 & 0.0 & 0.0 & 0.0 & 0.0 & 0.0 & 0.0 & 0.0 & 0.0 & 0.0 & 0.0 & 12 \\
\hline 1,3-(1,1-dimethylethyl)2Mxy-5 & 0.0 & 0.0 & 0.0 & 0.0 & 0.0 & 0.0 & 0.0 & 0.0 & 0.0 & 0.0 & 0.0 & 0.0 & 21 & 0.0 & 0.0 & 0.0 & 0.0 \\
\hline 2,3,5,6,Tetraflouroanisol & 0.0 & 0.0 & 0.0 & 0.0 & 0.0 & 0.0 & 0.0 & 0.0 & 0.0 & 0.0 & 0.0 & 0.0 & 17 & 0.0 & 0.0 & 0.0 & 0.0 \\
\hline Azulene & 0.0 & 0.0 & 0.0 & 0.0 & 0.0 & 0.0 & 0.0 & 9.2 & 0.0 & 0.0 & 0.0 & 0.0 & 0.0 & 0.0 & 0.0 & 0.0 & 0.0 \\
\hline Eucalyptol & 0.0 & 10 & 0.3 & 2.3 & 2.3 & 0.0 & 0.0 & 0.0 & 0.0 & 0.0 & 0.0 & 0.0 & 0.0 & 0.0 & 0.0 & 0.0 & 0.0 \\
\hline
\end{tabular}

Note: *: A. Nasser et al. (2014); B. De laurentis et al. (2002); C. Haoui et al. (2011); D. Perez-Alonso et al. 1996); E. Alalan et al. (2015); F. Blanc et al. (2006); G. Camacho et al. (2000); H. Sevindik and Paksoy (2017); I. Al Qudah et al. (2010); J. Assi et al. (2014); K. Boudouda et al. (2012); L. Miguel et al. (2008); M. Marongiu et al. (2003) 


\section{MATERIALS AND METHODS}

\section{Plant material}

Inula viscosa $\mathrm{L}$. is an annual herbaceous, viscid and glandular plant with a strong odor. It can reach $50 \mathrm{~cm}$ to $1 \mathrm{~m}$ in height and has many flower heads with yellow flowers at the top of the stem (Quezel and Santa 1963) (Figure 1), locally it is called Magramen.

\section{The essential oil extraction}

Samples of $I$. viscosa were collected in the flowering stage from 15 localities in Algeria (Figure 2). The aerial parts were collected in October 2017. The air-dried materials were subjected to hydro-distillation for $3 \mathrm{~h}$ using a Clevenger apparatus type. Voucher specimens were deposited in the herbarium of the Department of Biology and Ecology, Setif-1 University, Algeria.

The oil obtained was collected and dried over anhydrous sodium sulfate and stored in screw-capped glass vials in a refrigerator at $4-5^{\circ} \mathrm{C}$ prior to analysis. The Essential oil yield was calculated by the following formula:

$$
\text { Yield in essential oil }(\%)=\frac{\text { Weight of the essential oil }}{\text { Weight of the plant used }} \times 100
$$

\section{Essential oil analysis}

The essential oils were analyzed using a HewlettPackard gas chromatograph (CG/FID 7890), coupled to a gas chromatograph (CG/MS 7890/5975C), equipped with a Column Apolar: DB5 MS: $40 \mathrm{~m} 0.18 \mathrm{~mm} 0.18 \mu \mathrm{m}$ and programming from $50^{\circ} \mathrm{C}$ for $5 \mathrm{~min}$ at rate of $5^{\circ} \mathrm{C} / \mathrm{min}$ up to $300^{\circ} \mathrm{C}$. Helium was used as the carrier gas $(1.0 \mathrm{ml} / \mathrm{min})$; injection in the split mode (1:30), injector and detector temperature of $280^{\circ} \mathrm{C}$ with split $1 / 100$. The mass spectrometer worked in the EI mode at $70 \mathrm{eV}$; electron multiplier, $2500 \mathrm{~V}$; ion source temperature, $180^{\circ} \mathrm{C}$; the MS data were acquired in the scan mode in the $\mathrm{m} / \mathrm{z}$ range of 33 450. The identification of the components was based on the comparison of their mass spectra with those of NIST mass spectral library (Masada 1976; NIST 2002) and those described by Adams, and the comparison of their retention indices either with those of authentic compounds or with literature values (Adams 2007).

\section{Antimicrobial Activity}

The antimicrobial activities of the essential oil of $I$. viscosa were evaluated against six Gram-positive bacteria (Staphylococcus aureus ATCC2592, S. aureus SARM, Listeria innocua CLIP 74915, L. Monocytogenes, Bacillus cereus ATCC 11778 and Enterococcus faecalis, and nine Gram-negative bacteria (Pseudomonas aeruginosa ATCC 27853, Klebsiella pneumoniae ATCC700603, Escherichia coli ATCC 25922, Proteus mirabilis ATCC35659, Enterobacter cloacae, Acetobacter, Serratia marcescens, $S$. liquefaciens, ESBL/BLSE and Salmonella enterica. Bacterial inoculums were prepared from overnight broth culture in physiological saline $(0.8 \%$ of $\mathrm{NaCl})$ to obtain an optical density ranging from 0.08 to 0.1 at $625 \mathrm{~nm}$. Muller
Hinton agar (MH agar) and MH agar supplemented with $5 \%$ sheep blood for fastidious bacteria were placed in Petri dishes, solidified, and surface dried before inoculation. Sterile discs $(6 \mathrm{~mm})$ were placed on inoculated agars, by test bacteria, filled with $10 \mu \mathrm{l}$ of undiluted and diluted essential oil $(1 / 1,1 / 2,1 / 3 \mathrm{v} / \mathrm{v}$ of DMSO). DMSO was used as a negative control, and the antibiotic Gentamicin is used as positive control. The bacterial growth inhibition was determined as the diameter of the inhibition zones around the discs. All the tests were performed in triplicate, and the means were calculated as results. The Petri dishes were incubated at $37^{\circ} \mathrm{C}$ for 18 to $24 \mathrm{~h}$ aerobically. After incubation, inhibition zone diameters were measured and documented (Dahiya and Purkayastha 2012). The sensitivity to the essential oil was classified according to the diameter of the inhibition halos as follows: not sensitive (-) for diameters less than $8 \mathrm{~mm}$; sensitive (+) for diameters ranging from 9 to $14 \mathrm{~mm}$; very sensitives (++) for diameters ranging from $15-19 \mathrm{~mm}$ and extremely sensitive (+++) for diameters larger than $20 \mathrm{~mm}$ (Ponce et al. 2003).

\section{Statistical analysis}

The data were first subjected to the Principal Components Analysis (PCA) to examine the relationships among the terpenes compounds and identify the possible structure of the populations. Cluster analysis (UPGMA) was carried out on the original variables and on the Manhattan distance matrix to seek for hierarchical associations among the populations. The cluster analyses were carried out using Statistica v10 software. The antibacterial activity results were analyzed by the ANOVA three-way Completely Randomized (populations, doses, and bacteria) by using the CoStat statistical software package. All analyses were performed at the $5 \%$ significance level $(\mathrm{P}<0.05)$.

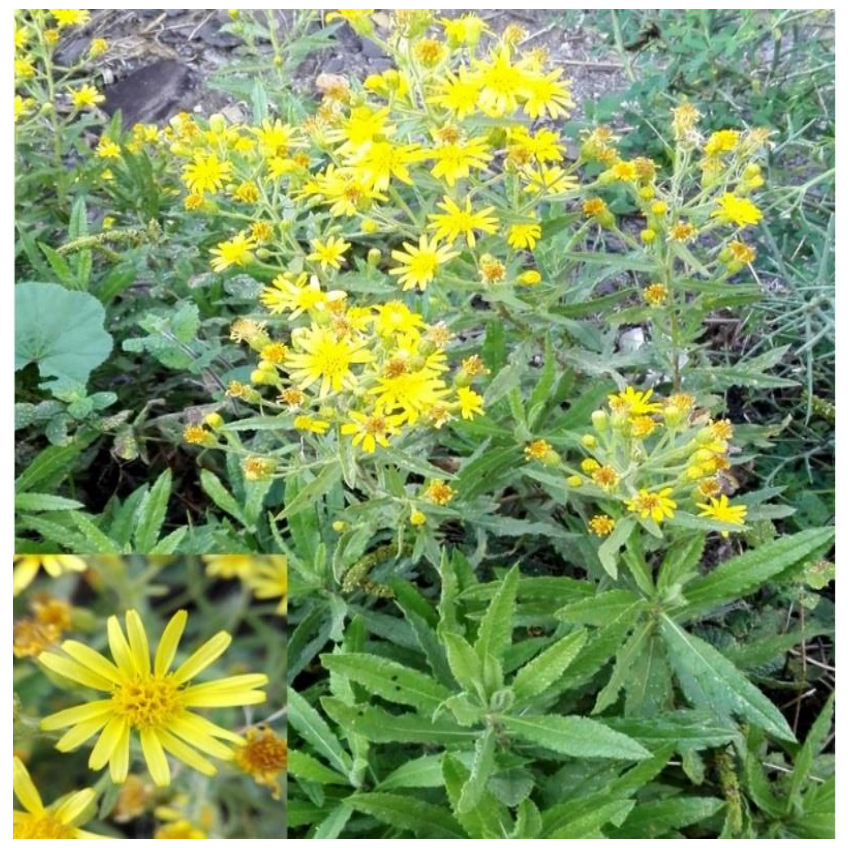

Figure 1. Inula viscosa $\mathrm{L}$. 


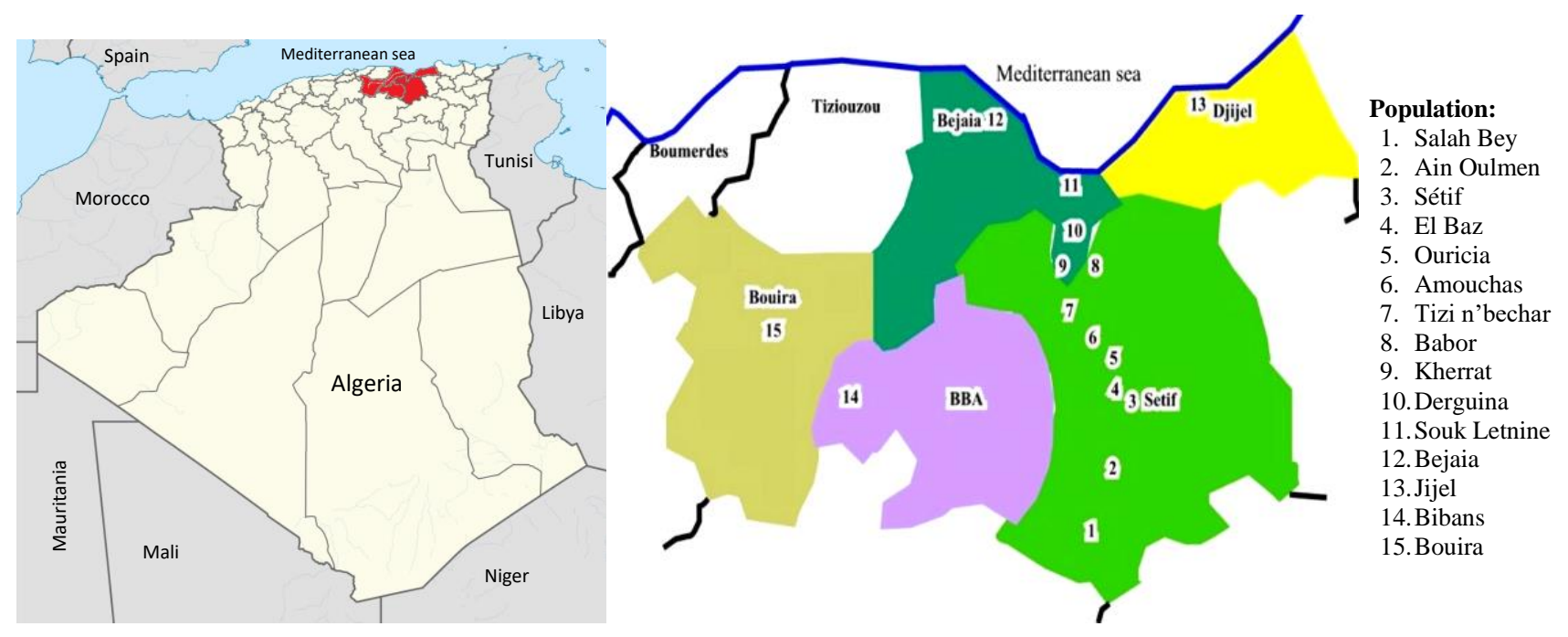

Figure 2. Populations of Inula viscosa sampled in Algeria

\section{RESULTS AND DISCUSSION}

The hydro-distillation of Inula viscosa essential oils gave a yellow-colored viscous liquid. The average yield of the essential oils was $0.23 \pm 0.06 \%$. The analysis of the composition of the essential oils was carried out using (GC-MS) (Figure 3).

The identified components and their relative abundances are presented in the order of their appearance (Table 2). Seventy-five chemical compounds, with an average of $38 \pm 4$, were identified in I. viscosa essential oils, representing an average of $98.06 \pm 2.03 \%$ of the total oils.

The chemical composition of the essential oils of $I$. viscosa populations is very different, but it is dominated by the presence of polygodial $(19.8 \pm 16.97 \%)$, phytol $(12.3 \pm$ $9.77 \%)$, fokienol $(6.01 \pm 3.43 \%)$, intermedeol neo $(5.09 \pm$ $2.38 \%)$, caryophyllene oxide $(4.91 \pm 3.03 \%)$, nerolidol-Z $(4.46 \pm 5.46 \%)$, nerolidol-E $(4.24 \pm 8.07 \%)$ and $\alpha$-ionone iso methyl-E $(3.72 \pm 2.26 \%)$.

The composition of $I$. viscosa essential oils shows significant differences. The concentrations of these components show notable inter-population variability (Figure 4). The compounds that show the largest variation are $\beta$-acoradienol (RSD 353), canellal (RSD 339) farnesol (2Z, 2E) (RSD 231) and retene (RSD 214).

The canellal, with an average of $0.51 \pm 1.69 \%$ is the component that exhibits the greatest variation in this species, followed by retene $(0.64 \pm 1.38 \%), \gamma$-ionone iso methyl, nerolidol-Z, Eicosane-1, geranyl acetone, $\alpha$ muurolene 14-oxy, linoleic acid, aromadrene epoxide allo, nerolidol-E.

Camphor occurs in Biban and El Bez populations with a high content 7.58 and $3.34 \%$ respectively. The populations of Bouira and Babor isolate themselves with high levels of aromadrene epoxide-allo (7.1 and 5.33\%). Farnesol (2Z, $6 \mathrm{E})$ is present in the oils of three populations Bouira, Bibans and Bejaia with appreciable levels 5.69, 1.67 and $2.36 \%$ respectively. The population of Setif is individualized by the presence of $\beta$-acoradienol with a concentration of $5.95 \%$. The canellal is present only in Kherrata and Amoucha populations with contents of 1.19 and $6.53 \%$. The populations of Bouira, Ain Oulmen, and Salah Bey contain appreciable levels of retene, 3.73, 4.04 and $1.57 \%$ respectively.

I. viscosa populations show very little differences in the total concentrations of the essential oils. To compare profiles with chemical compounds we considered each compound as a quantitative variable. The spatial threedimensional projection of the 15 populations based on the three main axes from the PCA (Figure 5), shows that the populations of Salah Bey, Ain oulemen, Souk Letnine, Bibans, and Tizi n'Bechar are distinctly separated, but the rest of the populations studied are not clearly distinguished and their separation into homogeneous groups is less clear.

The UPGMA clusters analysis based on the linkage distance, confirms the results of the PCA and separates I. viscosa populations in two distinct clades. This clustration of the populations in small groups indicates differences in the chemical composition of the essential oils (Figure 6). The essential oils of the first cluster, the Salah Bey population, is characterized by a high content of polygodial and important concentrations of phytol and intermedeolneo.

The second cluster is composed of two subgroups: the first group that includes the populations of Ain Oulemen, Babor, Jijel, Bibans, Bejaia, and Bouira is characterized by a high level of fokienol, Polygodial and Nerolidol-Z.

The second group includes the populations of Ouricia, Derguina, Bibans, Tizi n'Bechar, Setif, Amoucha, El baz, and Kherrata is characterized by the presence of high levels of fokienol, phytol, intermedeol-neo, geranyl acetone, and nerolidol-E. Based on the chemical and statistical results of Inula viscosa populations, several chemotypes can be identified (Table 3).

The Antibacterial activity of the essential oils of I. viscosa is evaluated by the disc method. The diameters of inhibition of the bacterial strains were determined by 
measuring the diameter of the inhibition halos after 24 hours of incubation at $37^{\circ} \mathrm{C}$ (Table 4). The results of the antibacterial assay of $\mathrm{I}$. viscosa essential oils against several bacteria strains showed that P. aeruginosa, K. pneumoniae, S. aureus ESBL and S. enterica bacterial species were extremely sensitive to the essential oils of all the populations tested.

Based on the statistical analyzes, the results showed that the interaction of the sampling sites, dilution levels and strain of the bacteria were highly significant $(\mathrm{P}<0.001)$ (Table 5).
The I. viscosa essential oils from Setif and Ain Oulmene region exhibits high antimicrobial activity against the bacterial species tested with an average inhibition diameter of 18.72 and $18.55 \mathrm{~mm}$ respectively (Table 6). The oils of these two populations have the highest inhibitory potency among the populations studied (Figure 7); while the oil of Amoucha population is the least active against the bacterial species. This latter is classified in the last group (g) with an average inhibition diameter of $17.19 \mathrm{~mm}$ (Table $6)$.
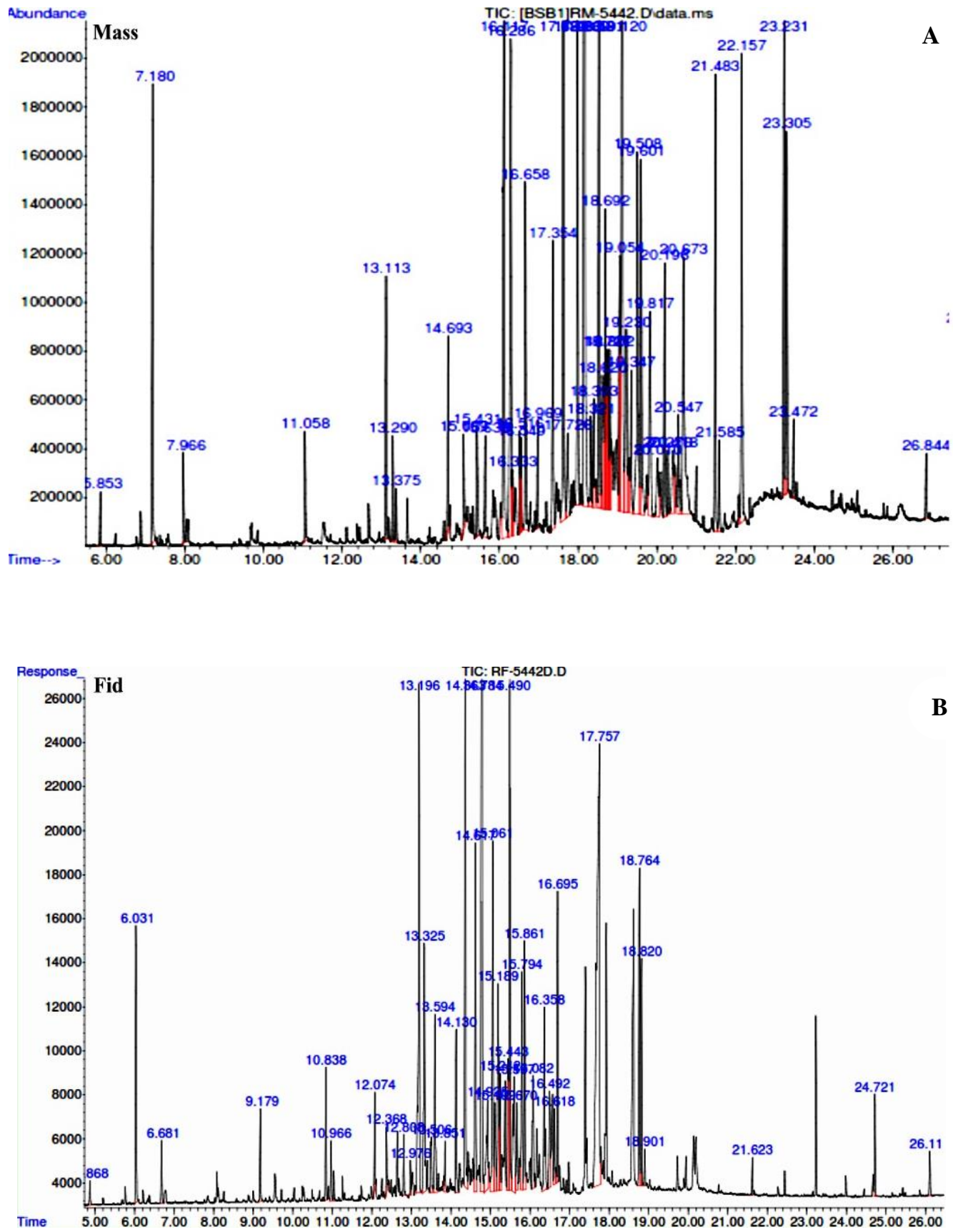

Figure 3. Essential oil chromatogram for Bejaia Inula viscosa. A. Mass Spectrophotometer, B. Fid 
Table 2. Chemical composition of the essential oils of Inula viscosa

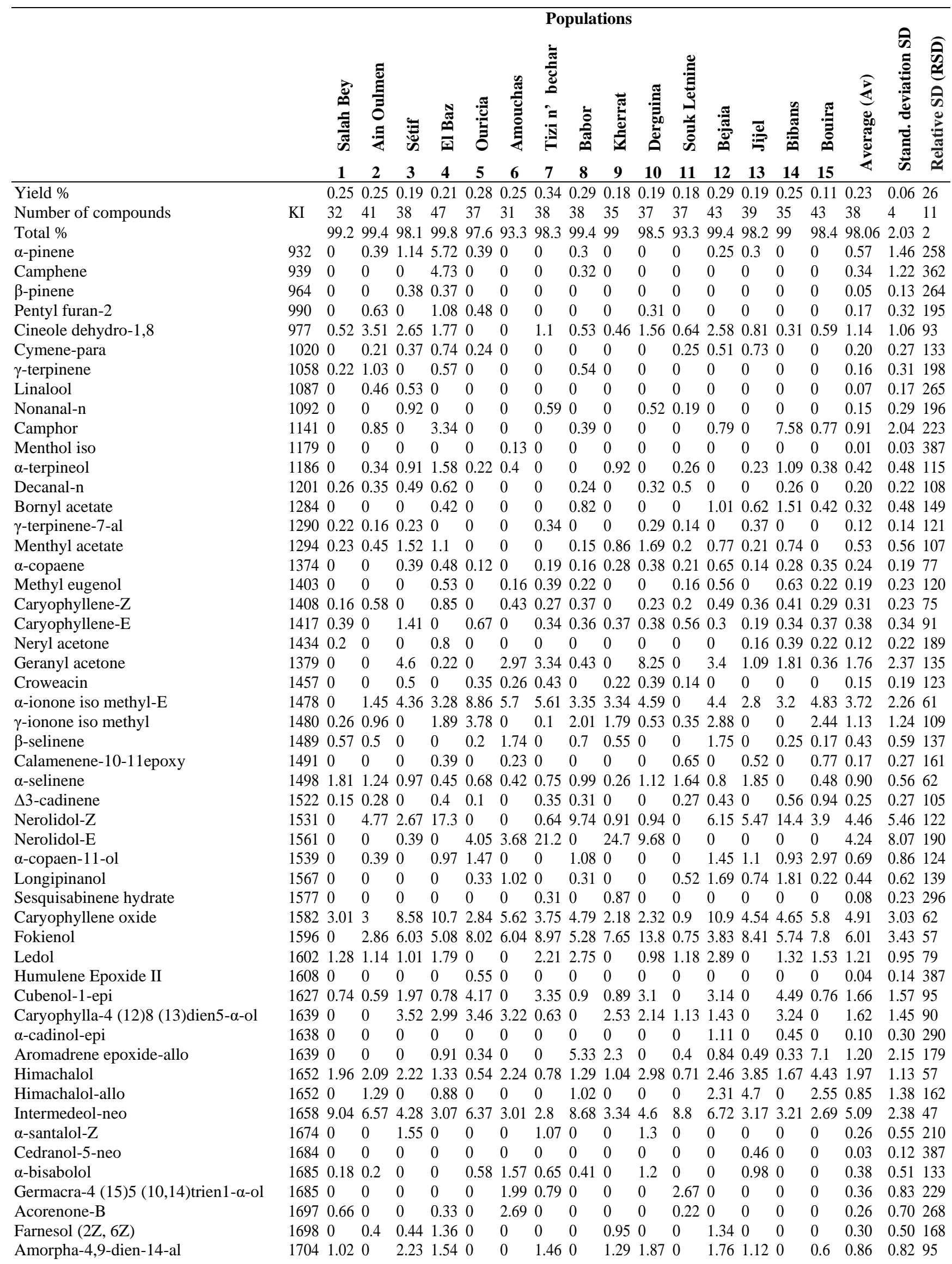


Thujopsenal

Farnesol (2Z, 6E)

$\alpha$-sinensal

$\beta$-costal

$\beta$-acoradienol

$\gamma$-curcumen-15-al

$\alpha$-costol

$\alpha$-muurolene 14-oxy

Isovalencenol-E

Phenyl ethyl acetate

Eicosane-1

Manool oxide

Canellal

Polygodial

Phytol

Linoleic acid

Retene

Tricosane

Tetracosane

Hexacosane

Heptacosane

Untriacontane $\begin{array}{lllllllllllllllllll}1708 & 2.05 & 2.82 & 1.65 & 0.76 & 0.51 & 1.47 & 1.23 & 1.64 & 0.79 & 0.56 & 3.65 & 2.09 & 1.98 & 0 & 1.74 & 1.53 & 0.95 & 62\end{array}$ $\begin{array}{lllllllllllllllllll}1722 & 0 & 0.41 & 0 & 0 & 0 & 0 & 0 & 0 & 0 & 0 & 0 & 2.36 & 0 & 1.67 & 5.69 & 0.68 & 1.56 & 231\end{array}$ $\begin{array}{lllllllllllllllllll}1755 & 0 & 0 & 0 & 0 & 0.94 & 0 & 0 & 0 & 0 & 1.73 & 0 & 0 & 0 & 0 & 0 & 0.18 & 0.49 & 277\end{array}$ $\begin{array}{lllllllllllllllllll}1766 & 0.87 & 1.45 & 1.32 & 0.81 & 1.17 & 0 & 1.37 & 0.77 & 1.37 & 0 & 0.9 & 1.43 & 0.72 & 1 & 1.35 & 0.97 & 0.47 & 49\end{array}$ $\begin{array}{lllllllllllllllllll}1762 & 0 & 0 & 5.95 & 0 & 0 & 0.56 & 0 & 0 & 0 & 0 & 0 & 0 & 0 & 0 & 0 & 0.43 & 1.53 & 353\end{array}$ $\begin{array}{lllllllllllllllllll}1766 & 0 & 0 & 1.98 & 1.2 & 0.72 & 2 & 0.8 & 0.51 & 1.7 & 0.64 & 0 & 0.66 & 1.92 & 0.33 & 0.9 & 0.89 & 0.72 & 81\end{array}$ $\begin{array}{lllllllllllllllllll}1773 & 1.02 & 3.99 & 3.23 & 0.79 & 1.15 & 4.5 & 1.15 & 1.74 & 3.06 & 1.96 & 7.94 & 2.57 & 1.26 & 1.37 & 2.36 & 2.54 & 1.87 & 74\end{array}$

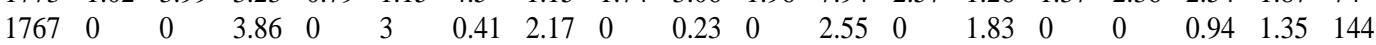
$\begin{array}{lllllllllllllllllll}1793 & 0 & 0 & 0 & 1.28 & 0 & 0 & 0 & 0 & 0 & 0 & 0 & 1.83 & 1.85 & 0 & 0.3 & 0.35 & 0.69 & 197\end{array}$ $\begin{array}{lllllllllllllllllll}1254 & 0 & 0 & 0 & 0 & 0.77 & 0.27 & 0 & 0 & 1.85 & 0 & 0 & 0 & 0 & 0 & 0 & 0.19 & 0.50 & 261\end{array}$ $\begin{array}{lllllllllllllllllll}1987 & 2.01 & 2.11 & 0 & 1.13 & 0 & 0 & 0 & 3.85 & 0 & 0 & 0 & 2.78 & 0.28 & 0.46 & 1.14 & 0.92 & 1.23 & 134\end{array}$ $\begin{array}{lllllllllllllllllll}1987 & 0 & 1.53 & 0 & 0 & 0 & 0 & 0 & 0 & 0 & 0 & 0 & 0.3 & 0 & 0 & 0 & 0.12 & 0.40 & 325\end{array}$ $\begin{array}{lllllllllllllllllll}2045 & 0 & 0 & 0 & 0 & 0 & 6.53 & 0 & 0 & 1.19 & 0 & 0 & 0 & 0 & 0 & 0 & 0.51 & 1.69 & 329\end{array}$ $\begin{array}{lllllllllllllllllll}2016 & 58.7 & 42.9 & 3.56 & 5 & 11.4 & 4.31 & 4.24 & 31.1 & 8.66 & 2.81 & 26.9 & 14.2 & 33.9 & 31.1 & 18.3 & 19.8 & 16.9 & 86\end{array}$ $\begin{array}{lllllllllllllllllll}1942 & 6.46 & 0.97 & 17.6 & 7.09 & 24.3 & 28.9 & 22.6 & 5.56 & 18.7 & 18.6 & 21.6 & 0 & 8.08 & 1.01 & 3.12 & 12.3 & 9.77 & 79\end{array}$ $\begin{array}{lllllllllllllllllll}2132 & 0 & 0.24 & 0.42 & 0 & 1.25 & 0 & 0.43 & 0 & 0 & 2.98 & 3.23 & 0 & 0 & 0 & 2.54 & 0.74 & 1.18 & 160\end{array}$ $\begin{array}{lllllllllllllllllll}2214 & 1.57 & 4.04 & 0 & 0 & 0 & 0 & 0 & 0 & 0 & 0 & 0 & 0.31 & 0 & 0 & 3.73 & 0.64 & 1.38 & 214\end{array}$ $\begin{array}{lllllllllllllllllll}2300 & 0.34 & 0.26 & 0 & 0 & 0.29 & 0 & 1.2 & 0 & 0.36 & 1.21 & 0.34 & 0 & 0.18 & 0 & 0.29 & 0.30 & 0.40 & 133\end{array}$ $\begin{array}{lllllllllllllllllll}2400 & 0.23 & 1.34 & 0 & 0.67 & 0 & 0 & 0 & 0 & 0 & 0 & 0 & 0.87 & 0.48 & 0.34 & 0.22 & 0.28 & 0.41 & 147\end{array}$ $\begin{array}{lllllllllllllllllll}2600 & 0.7 & 0 & 0 & 0 & 1.03 & 0 & 0 & 0.49 & 0.5 & 0.91 & 0.61 & 0 & 0.32 & 0 & 0.93 & 0.37 & 0.40 & 108\end{array}$ $\begin{array}{lllllllllllllllllll}2700 & 2.04 & 0 & 1.74 & 0 & 1.86 & 0.52 & 0.53 & 0 & 1.93 & 0.32 & 0.28 & 0 & 0 & 0 & 1.43 & 0.71 & 0.83 & 117\end{array}$ $\begin{array}{llllllllllllllllllll}3100 & 0.37 & 0.62 & 0.85 & 0.35 & 0.51 & 0.27 & 0.24 & 0 & 1.06 & 1.39 & 1.64 & 0.4 & 0 & 0.23 & 0.44 & 0.56 & 0.48 & 86\end{array}$

Table 3. Chemotypes of Inula viscosa populations

\begin{tabular}{ll}
\multicolumn{1}{c}{ Chemotypes } & \multicolumn{1}{c}{ Populations } \\
\hline Polygodial-Intermedeol neo-Phytol & Salah Bey \\
Fokinol-Polygodial-Nerolidol-Z & Ain Oulemen, Babor, Jijel, Biban, Bejaia, Bouira \\
Fokinol-Polygodial-Phytol & Souk Letnine \\
Fokienol-Phytol-Nerolidol-E & Sétif, Derguina, Ouricia, Amouchas, Tizi n'Bechar, kherrata \\
Fokienol-Phytol-Nerolidol-Z & El-baz \\
\hline
\end{tabular}

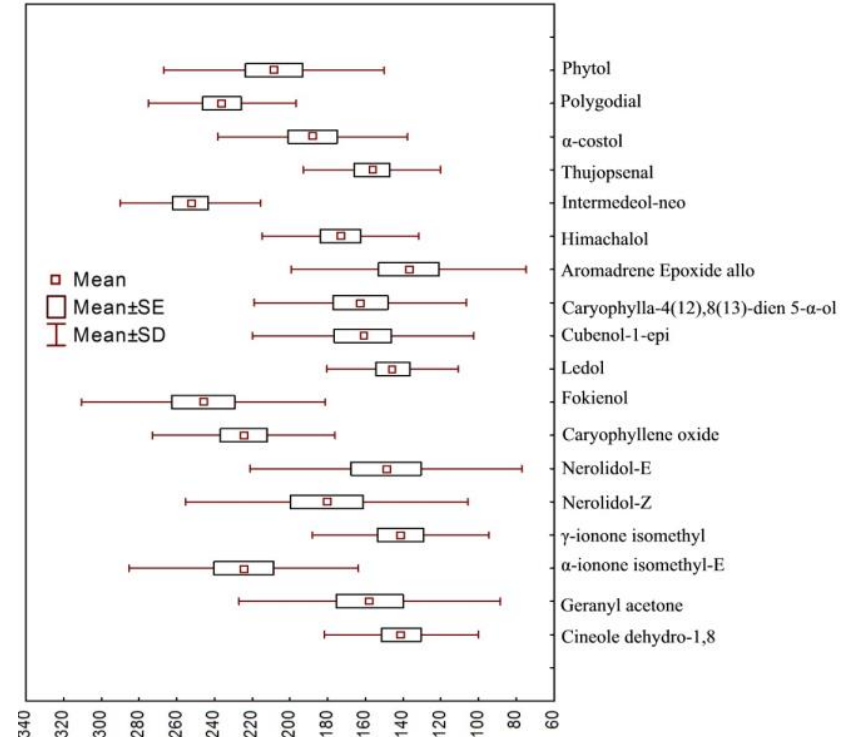

Figure 4. Variability of the essential oils major components of Inula viscosa.

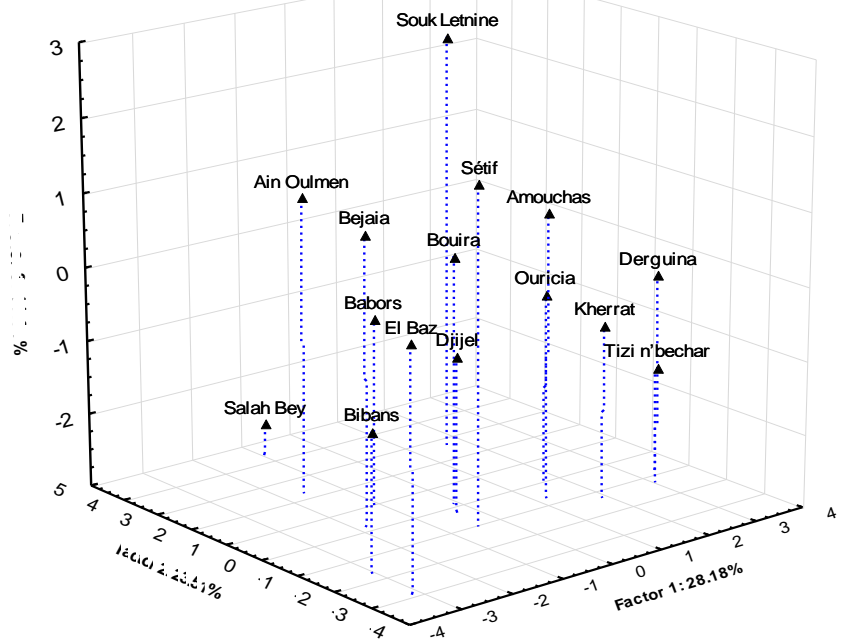

Figure 5. Three-dimensional spatial projection of Inula viscosa populations 
Table 4. Inhibition diameter (mm) of Inula viscosa essential oils

\begin{tabular}{|c|c|c|c|c|c|c|c|c|c|c|c|c|c|c|c|c|}
\hline & 莫 & 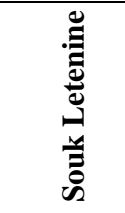 & 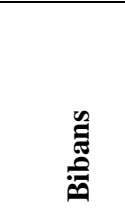 & 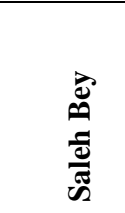 & 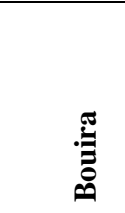 & 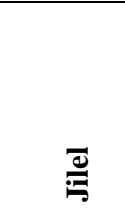 & 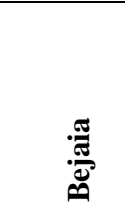 & 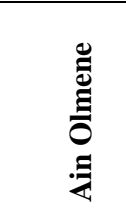 & ڤ̈. & 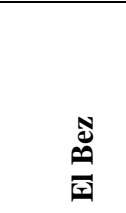 & 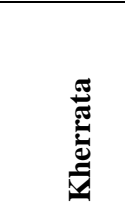 & & 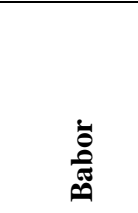 & 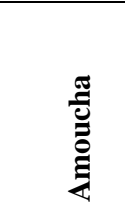 & 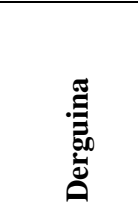 & 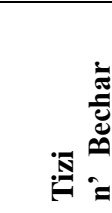 \\
\hline \multirow[t]{4}{*}{ P. aeruginosa } & 1 & $10.3 \pm 0.6$ & $11.3 \pm 1.2$ & $10 \pm 0$ & $13.3 \pm 1.2$ & $10.7 \pm 1.2$ & $12 \pm 1$ & $22.3 \pm 0.6$ & $22 \pm 1.7$ & $10.3 \pm 0.6$ & $15.7 \pm 0.6$ & $13 \pm 0$ & $22.3 \pm 0.6$ & $14.3 \pm 1.2$ & $13 \pm 2$ & $10.3 \pm 0.6$ \\
\hline & $1 / 2$ & $12.3 \pm 0.6$ & $12.3 \pm 0.6$ & $12 \pm 1.7$ & $11.7 \pm 0.6$ & $11.3 \pm 1.2$ & $11.3 \pm 1.2$ & $15 \pm 1$ & $14.7 \pm 0.6$ & $12.3 \pm 1.2$ & $12.3 \pm 0.6$ & $10 \pm 0$ & $16 \pm 1$ & $12.3 \pm 0.6$ & $10.7 \pm 1.2$ & $12.3 \pm 1.2$ \\
\hline & $1 / 3$ & $11 \pm 1.7$ & $10.7 \pm 1.2$ & $10 \pm 0$ & $11.7 \pm 1.2$ & $11 \pm 1$ & $11.7 \pm 1.2$ & $13 \pm 1.7$ & $13.7 \pm 0.6$ & $12 \pm 1$ & $10.3 \pm 0.6$ & $10 \pm 0$ & $12.7 \pm 1.2$ & $10 \pm 0$ & $12.3 \pm 0.6$ & $12 \pm 1$ \\
\hline & GEN & $31.9 \pm 0.1$ & $31.9 \pm 0.1$ & $31.9 \pm 0.1$ & $31.9 \pm 0.1$ & $31.9 \pm 0.1$ & $31.9 \pm 0.1$ & $31.9 \pm 0.1$ & $31.9 \pm 0.1$ & $31.9 \pm 0.1$ & $31.9 \pm 0.1$ & $31.9 \pm 0.1$ & $31.9 \pm 0.1$ & $31.9 \pm 0.1$ & $31.9 \pm 0.1$ & $31.9 \pm 0.1$ \\
\hline \multirow[t]{4}{*}{ K. pneumoniae } & 1 & $30 \pm 0$ & $25 \pm 0$ & $22 \pm 0$ & $20.3 \pm 0.6$ & $20 \pm 0$ & $20 \pm 0$ & $30 \pm 0$ & $25 \pm 0$ & $22.7 \pm 0.6$ & $23.7 \pm 1.5$ & $28 \pm 0$ & $28 \pm 0$ & $23.3 \pm 1.5$ & $23.7 \pm 1.2$ & $21.7 \pm 2.9$ \\
\hline & $1 / 2$ & $20.6 \pm 1.2$ & $20.7 \pm 1.2$ & $18 \pm 0$ & $16.7 \pm 0.6$ & $19.7 \pm 0.6$ & $25 \pm 0$ & $12 \pm 0$ & $20.7 \pm 1.2$ & $15 \pm 0$ & $16 \pm 0$ & $17.3 \pm 0.6$ & $15.3 \pm 0.6$ & $15 \pm 0$ & $15 \pm 0$ & $13.7 \pm 0.6$ \\
\hline & $1 / 3$ & $15 \pm 0$ & $16.7 \pm 1.2$ & $14 \pm 0$ & $13.3 \pm 0.6$ & $16.7 \pm 1.2$ & $20 \pm 0$ & $18 \pm 0$ & $15 \pm 0$ & $18.3 \pm 2.9$ & $15 \pm 0$ & $15 \pm 0$ & $12.7 \pm 1.2$ & $20 \pm 0$ & $20 \pm 0$ & $13.3 \pm 0.6$ \\
\hline & GEN & $27.9 \pm 0.1$ & $27.9 \pm 0.1$ & $27.9 \pm 0.1$ & $27.9 \pm 0.1$ & $27.9 \pm 0.1$ & $27.9 \pm 0.1$ & $27.9 \pm 0.1$ & $27.9 \pm 0.1$ & $27.9 \pm 0.1$ & $27.9 \pm 0.1$ & $27.9 \pm 0.1$ & $27.9 \pm 0.1$ & $27.9 \pm 0.1$ & $27.9 \pm 0.1$ & $27.9 \pm 0.1$ \\
\hline \multirow[t]{4}{*}{ E. coli } & 1 & $15 \pm 0$ & $13.3 \pm 4.2$ & $13 \pm 0$ & $11.3 \pm 0.6$ & $10.3 \pm 0.6$ & $10.7 \pm 1.2$ & $17.7 \pm 2.5$ & $14.3 \pm 1.2$ & $14.3 \pm 1.2$ & $10.3 \pm 0.6$ & $13 \pm 1.7$ & $13 \pm 1.7$ & $19.3 \pm 1.2$ & $11.7 \pm 1.2$ & $14.3 \pm 0.6$ \\
\hline & $1 / 2$ & $13.3 \pm 2.9$ & $12 \pm 1.7$ & $11.3 \pm 1.2$ & $11.7 \pm 1.5$ & $14.3 \pm 1.2$ & $10 \pm 0$ & $14.3 \pm 1.2$ & $11.3 \pm 1.2$ & $13.3 \pm 1.5$ & $10 \pm 0$ & $11 \pm 0$ & $10.7 \pm 0.6$ & $13.7 \pm 1.5$ & $10 \pm 0$ & $10.7 \pm 0.6$ \\
\hline & $1 / 3$ & $14.3 \pm 1.2$ & $11.3 \pm 1.2$ & $10 \pm 0$ & $12 \pm 1.7$ & $10.7 \pm 1.2$ & $10.3 \pm 0.6$ & $13.7 \pm 1.5$ & $10.7 \pm 0.6$ & $11.7 \pm 0.6$ & $10.3 \pm 0.6$ & 10.30 .6 & $10 \pm 0$ & $10.7 \pm 1.2$ & $8.7 \pm 1.2$ & $10 \pm 0$ \\
\hline & GEN & $39.9 \pm 0.1$ & $39.9 \pm 0.1$ & $39.9 \pm 0.1$ & $39.9 \pm 0.1$ & $39.9 \pm 0.1$ & $39.9 \pm 0.1$ & $39.9 \pm 0.1$ & $39.9 \pm 0.1$ & $39.9 \pm 0.1$ & $39.9 \pm 0.1$ & $39.9 \pm 0.1$ & $39.9 \pm 0.1$ & $39.9 \pm 0.1$ & $39.9 \pm 0.1$ & $39.9 \pm 0.1$ \\
\hline \multirow[t]{4}{*}{ B. cereus } & 1 & $10.7 \pm 1.2$ & $15.7 \pm 1.2$ & $13 \pm 0$ & $11.3 \pm 0.6$ & $10 \pm 0$ & $15 \pm 0$ & $12.7 \pm 0.6$ & $11.7 \pm 0.6$ & $15.3 \pm 1.5$ & $12.7 \pm 0.6$ & $20 \pm 0$ & $10.3 \pm 0.6$ & $10.7 \pm 0.6$ & $13 \pm 0$ & $15 \pm 0$ \\
\hline & $1 / 2$ & $10.7 \pm 0.6$ & $10 \pm 0$ & $10 \pm 0$ & $11 \pm 1$ & $10 \pm 0$ & $10 \pm 0$ & $10 \pm 0$ & $10 \pm 0$ & $10 \pm 0$ & $10.3 \pm 0.6$ & $11 \pm 0$ & $10 \pm 0$ & $10 \pm 0$ & $10 \pm 0$ & $10.3 \pm 0.6$ \\
\hline & $1 / 3$ & $10.7 \pm 1.2$ & $10.7 \pm 1.2$ & $11 \pm 0$ & $10.7 \pm 0.6$ & $8 \pm 0$ & $8.7 \pm 1.2$ & $10 \pm 0$ & $10 \pm 0$ & $11 \pm 0$ & $9.3 \pm 0.6$ & $10 \pm 0$ & $10.7 \pm 0.6$ & $10.6 \pm 0.6$ & $11.3 \pm 0.6$ & $10 \pm 0$ \\
\hline & GEN & $22.9 \pm 0.1$ & $22.9 \pm 0.1$ & $22.9 \pm 0.1$ & $22.9 \pm 0.1$ & $22.9 \pm 0.1$ & $22.9 \pm 0.1$ & $22.9 \pm 0.1$ & $22.9 \pm 0.1$ & $22.9 \pm 0.1$ & $22.9 \pm 0.1$ & $22.9 \pm 0.1$ & $22.9 \pm 0.1$ & $22.9 \pm 0.1$ & $22.9 \pm 0.1$ & $22.0 \pm 0.1$ \\
\hline \multirow[t]{4}{*}{ S. aureus } & 1 & $15.7 \pm 1.2$ & $30 \pm 0$ & $29.3 \pm 1.2$ & $30 \pm 0$ & $30 \pm 0$ & $28.7 \pm 1.2$ & $30 \pm 0$ & $32.7 \pm 1.2$ & $32.7 \pm 0.6$ & $29.3 \pm 1.2$ & $29.3 \pm 1.2$ & $29.3 \pm 1.2$ & $29.3 \pm 1.2$ & $30 \pm 0$ & $30 \pm 0$ \\
\hline & $1 / 2$ & $14.3 \pm 1.2$ & $25.3 \pm 0.6$ & $21.7 \pm 2.9$ & $27 \pm 1.7$ & $28.7 \pm 1.2$ & $28 \pm 0$ & $28 \pm 0$ & $28.7 \pm 1.2$ & $27.3 \pm 1.2$ & $18.7 \pm 1.2$ & $26 \pm 1.7$ & $26 \pm 1.7$ & $26 \pm 1.7$ & $28 \pm 0$ & $28 \pm 0$ \\
\hline & $1 / 3$ & $13.3 \pm 0.6$ & $22 \pm 2$ & $24.7 \pm 0.6$ & $25 \pm 0$ & $28 \pm 0$ & $25.7 \pm 1.2$ & $28 \pm 0$ & $24.3 \pm 1.2$ & $25.3 \pm 0.6$ & $15 \pm 0$ & $24.7 \pm 0.6$ & $22.7 \pm 1.2$ & $19.3 \pm 1.2$ & $26.7 \pm 1.2$ & $19.3 \pm 1.2$ \\
\hline & GEN & $29.9 \pm .1$ & $29.9 \pm 0.1$ & $29.9 \pm 0.1$ & $29.9 \pm 0.1$ & $29.9 \pm 0.1$ & $29.9 \pm 0.1$ & $29.9 \pm 0.1$ & $29.9 \pm 0.1$ & $29.9 \pm 0.1$ & $29.9 \pm 0.1$ & $29.9 \pm 0.1$ & $29.9 \pm 0.1$ & $29.9 \pm 0.1$ & $29.9 \pm 0.1$ & $29.9 \pm 0.1$ \\
\hline \multirow[t]{4}{*}{ S. aureus (SARM) } & 1 & $28 \pm 0$ & $13.3 \pm 0.6$ & $19.3 \pm 1.2$ & $19.7 \pm 0.6$ & $16.7 \pm 1.5$ & $15 \pm 1.7$ & $14 . \pm 1$ & $23.7 \pm 1.2$ & $19.3 \pm 1.2$ & $19.3 \pm 1.2$ & $20.3 \pm 0.6$ & $18.7 \pm 1.2$ & $13.3 \pm 0.6$ & $16.3 \pm 1.2$ & $19.3 \pm 1.2$ \\
\hline & $1 / 2$ & $25.3 \pm 0.6$ & $20 \pm 0$ & $18.7 \pm 2.3$ & $17.7 \pm 2.5$ & $16.3 \pm 1.5$ & $13.7 \pm 1.5$ & $11.3 \pm 1.5$ & $17.7 \pm 2.3$ & $12.3 \pm 1.2$ & $13.7 \pm 1.2$ & $15.3 \pm 2.5$ & $17 \pm 1$ & $13 \pm 0$ & $14.7 \pm 1.5$ & $13 \pm 1.7$ \\
\hline & $1 / 3$ & $20.7 \pm 1.2$ & $15 \pm 0$ & $15 \pm 0$ & $16.7 \pm 2.9$ & $14.3 \pm 1.2$ & $17.3 \pm 2.5$ & $16 \pm 1$ & $17.7 \pm 0.6$ & $14.3 \pm 1.2$ & $12 \pm 0$ & $16.7 \pm 1.5$ & $11 \pm 1$ & $12.7 \pm 0.6$ & $10.3 \pm 0.6$ & $12 \pm 0$ \\
\hline & GEN & $34.9 \pm 0.1$ & $34.9 \pm 0.1$ & $34.9 \pm 0.1$ & $34.9 \pm 0.1$ & $34.9 \pm 0.1$ & $34.9 \pm 0.1$ & $34.9 \pm 0.1$ & $34.9 \pm 0.1$ & $34.9 \pm 0.1$ & $34.9 \pm 0.1$ & $34.9 \pm 0.1$ & $34.9 \pm 0.1$ & $34.9 \pm 0.1$ & $36.2 \pm 2.3$ & $34.9 \pm 0.1$ \\
\hline \multirow[t]{4}{*}{$E S B L$} & 1 & $12.3 \pm 0.6$ & $10.7 \pm 1.2$ & $10.3 \pm 0.6$ & $11 \pm 1$ & $13 \pm 0$ & $13.7 \pm 1.2$ & $15.7 \pm 0.6$ & $20 \pm 0$ & $20 \pm 0$ & $17.3 \pm 1.2$ & $19.3 \pm 1.2$ & $18.3 \pm 1.2$ & 15. \pm 0 & $10 \pm 0$ & $17.3 \pm 1.2$ \\
\hline & $1 / 2$ & $10.7 \pm 0.6$ & $11.3 \pm 1.2$ & $10 \pm 0$ & $10 \pm 0$ & $11 \pm 0$ & $12.3 \pm 0.6$ & $13 \pm 1.7$ & $14.7 \pm 1.5$ & $14.7 \pm 1.5$ & $12.7 \pm 0.6$ & $12.7 \pm 0.58$ & $10 \pm 0$ & $12.7 \pm 1.2$ & $11.7 \pm 2.9$ & $12.7 \pm 0.6$ \\
\hline & $1 / 3$ & $9.7 \pm 0.6$ & $10.3 \pm 0.6$ & $10 \pm 0$ & $10.7 \pm 0.6$ & $11 \pm 1$ & $13.3 \pm 1.2$ & $11 \pm 0$ & $12.7 \pm 1.2$ & $12.7 \pm 1.2$ & $11.7 \pm 0.6$ & $12.3 \pm 0.58$ & $11 \pm 1$ & $10.7 \pm 0.6$ & $11 \pm 0$ & $11.7 \pm 0.6$ \\
\hline & GEN & $39.9 \pm 0.1$ & $39.9 \pm 0.1$ & $39.9 \pm 0.1$ & $39.9 \pm 0.1$ & $39.9 \pm 0.1$ & $39.9 \pm 0.1$ & $39.9 \pm 0.1$ & $39.9 \pm 0.1$ & $39.9 \pm 0.1$ & $39.9 \pm 0.1$ & $39.9 \pm 0.1$ & $39.9 \pm 0.1$ & $39.9 \pm 0.1$ & $39.90 \pm 0.1$ & $39.9 \pm 0.1$ \\
\hline \multirow[t]{4}{*}{ L. monocytogenes } & 1 & $20 \pm 0$ & $12.3 \pm 2.5$ & $11.7 \pm 2.9$ & $14.3 \pm 1.2$ & $21 \pm 1.7$ & $10 \pm 0$ & $11 \pm 1$ & $10.7 \pm 1.2$ & $12.7 \pm 0.6$ & $11.3 \pm 0.6$ & $10.7 \pm 1.2$ & $11.33 \pm 0.6$ & $10 \pm 0$ & $10 \pm 0$ & $11.3 \pm 0.6$ \\
\hline & $1 / 2$ & $17.7 \pm 2.5$ & $11 \pm 1.7$ & $10 \pm 0$ & $12 \pm 1$ & $13.3 \pm 1.5$ & $10 \pm 0$ & $10.7 \pm 0.6$ & $10.3 \pm 0.6$ & $11.3 \pm 1.2$ & $10.3 \pm 0.6$ & $10 \pm 0$ & $10.3 \pm 0.6$ & $10.3 \pm 0.6$ & $10 \pm 0$ & $10.7 \pm 1.2$ \\
\hline & $1 / 3$ & $15 \pm 0$ & $10 \pm 0$ & $10 \pm 0$ & $10 \pm 0$ & $10 \pm 0$ & $10 \pm 0$ & $10.3 \pm 0.6$ & $10.7 \pm 1.2$ & $10 \pm 0$ & $10 \pm 0$ & $12.3 \pm 1.2$ & $12 \pm 1.7$ & $10 \pm 0$ & $8.7 \pm 1.2$ & $10 \pm 0$ \\
\hline & GEN & $34.9 \pm 0.1$ & $34.9 \pm 0.1$ & $34.9 \pm 0.1$ & $34.9 \pm 0.1$ & $34.9 \pm 0.1$ & $34.9 \pm 0.1$ & $34.9 \pm 0.1$ & $34.9 \pm 0.1$ & $34.9 \pm 0.1$ & $34.9 \pm 0.1$ & $34.9 \pm 0.1$ & $34.9 \pm 0.1$ & $34.9 \pm 0.1$ & $34.9 \pm 0.1$ & $34.9 \pm 0.1$ \\
\hline
\end{tabular}




\begin{tabular}{|c|c|c|c|c|c|c|c|c|c|c|c|c|c|c|c|c|}
\hline \multirow[t]{4}{*}{ E. faecalis } & 1 & $13.3 \pm 0.6$ & $17.7 \pm 0.6$ & $17.7 \pm 1.2$ & $20 \pm 0$ & $25 \pm 0$ & $12 \pm 0$ & $19.3 \pm 1.2$ & $20.3 \pm 0.6$ & $16.3 \pm 1.2$ & $18.7 \pm 1.2$ & $20.7 \pm 1.2$ & $18.7 \pm 1.2$ & $16 \pm 1.7$ & $13.3 \pm 0.6$ & $18 \pm 0$ \\
\hline & $1 / 2$ & $10 \pm 0$ & $12.3 \pm 0.6$ & $15.7 \pm 1.2$ & $11.7 \pm 0.6$ & $11.7 \pm 1.5$ & $11.3 \pm 0.6$ & $10 \pm 0$ & $11.6 \pm 0.6$ & $10 \pm 0$ & $12 \pm 0$ & $15 \pm 0$ & $11.3 \pm 0.6$ & $12.7 \pm 0.6$ & $11 \pm 0$ & $10 \pm 0$ \\
\hline & $1 / 3$ & $10 \pm 0$ & $11 \pm 1$ & $11 \pm 1$ & $11.3 \pm 1.2$ & $10 \pm 0$ & $10 \pm 0$ & $10 \pm 0$ & $11 \pm 0$ & $12.7 \pm 0.6$ & $10.3 \pm 0.6$ & $12 \pm 0$ & $10.7 \pm 0.6$ & $11 \pm 0$ & $10 \pm 0$ & $10 \pm 0$ \\
\hline & GEN & $12.9 \pm 0.1$ & $12.9 \pm 0.1$ & $12.9 \pm 0.1$ & $12.9 \pm 0.1$ & $12.9 \pm 0.1$ & $12.9 \pm 0.1$ & $12.9 \pm 0.1$ & $12.9 \pm 0.1$ & $12.9 \pm 0.1$ & $12.9 \pm 0.1$ & $12.9 \pm 0.1$ & $12.9 \pm 0.1$ & $12.9 \pm 0.1$ & $12.9 \pm 0.1$ & $12.9 \pm 0.1$ \\
\hline \multirow[t]{4}{*}{ S. enterica } & 1 & $25 \pm 0$ & $29.3 \pm 1.2$ & $30 \pm 0$ & $25 \pm 0$ & $30 \pm 0$ & $30 \pm 0$ & $30 \pm 0$ & $30 \pm 0$ & $30 \pm 0$ & $30 \pm 0$ & $29.3 \pm 1.2$ & $25 \pm 0$ & $15 \pm 0$ & $30 \pm 0$ & $27.3 \pm 1.2$ \\
\hline & $1 / 2$ & $15.3 \pm 1.5$ & $26 \pm 1.7$ & $25 \pm 0$ & $15 \pm 0$ & $30 \pm 0$ & $28.7 \pm 1.2$ & $28.7 \pm 1.2$ & $27 \pm 1.7$ & $21.3 \pm 1.2$ & $22 \pm 0$ & $25 \pm 0$ & $15.7 \pm 1.2$ & $13.7 \pm 1.5$ & $24.3 \pm 1.2$ & $25.3 \pm 0.6$ \\
\hline & $1 / 3$ & $15 \pm 0$ & $26 \pm 1.7$ & $27.7 \pm 2.5$ & $17.3 \pm 2.1$ & $28 \pm 0$ & $28 \pm 0$ & $30 \pm 2$ & $26 \pm 1.7$ & $25 \pm 0$ & $25 \pm 0$ & $23.7 \pm 1.2$ & $15 \pm 0$ & $11.3 \pm 1.2$ & $11 \pm 1.7$ & $25 \pm 0$ \\
\hline & GEN & $26.9 \pm 0.1$ & $26.9 \pm 0.1$ & $26.9 \pm 0.1$ & $26.9 \pm 0.1$ & $26.9 \pm 0.1$ & $26.9 \pm 0.1$ & $26.9 \pm 0.1$ & $26.9 \pm 0.1$ & $26.9 \pm 0.1$ & $26.9 \pm 0.1$ & $26.9 \pm 0.1$ & $26.9 \pm 0.1$ & $26.9 \pm 0.1$ & $26.9 \pm 0.1$ & $26.9 \pm 0.1$ \\
\hline \multirow[t]{4}{*}{ Acetobacter sp. } & 1 & $15.3 \pm 0.6$ & $12.3 \pm 2.1$ & $11 \pm 0$ & $10.3 \pm 0.6$ & $15 \pm 0$ & $10 \pm 0$ & $13.7 \pm 0.6$ & $10 \pm 0$ & $11 \pm 0$ & $11.7 \pm 0.6$ & $13 \pm 0$ & $12.3 \pm 0.6$ & $10 \pm 0$ & $11.3 \pm 1.2$ & $13.3 \pm 0.6$ \\
\hline & $1 / 2$ & $12.7 \pm 0.6$ & $10 \pm 0$ & $10.3 \pm 0.6$ & $11 \pm 0$ & $12 \pm 0$ & $10.7 \pm 0.6$ & $10 \pm 0$ & $10.3 \pm 0.6$ & $10 \pm 0$ & $11.3 \pm 0.6$ & $10 \pm 0$ & $10 \pm 0$ & $10 \pm 0$ & $14 \pm 0$ & $12.7 \pm 0.6$ \\
\hline & $1 / 3$ & $11 \pm 0$ & $8 \pm 0$ & $10.7 \pm 0.6$ & $11 \pm 1$ & $10.7 \pm 0.6$ & $8 \pm 0$ & $10 \pm 0$ & $10.7 \pm 0.6$ & $10 \pm 0$ & $11 \pm 0$ & $10 \pm 0$ & $10 \pm 0$ & $10 \pm 0$ & $10.7 \pm 0.6$ & $10 \pm 0$ \\
\hline & GEN & $24.9 \pm 0.1$ & $24.9 \pm 0.1$ & $24.9 \pm 0.1$ & $24.9 \pm 0.1$ & $24.9 \pm 0.1$ & $24.9 \pm 0.1$ & $24.9 \pm 0.1$ & $24.9 \pm 0.1$ & $24.9 \pm 0.1$ & $24.9 \pm 0.1$ & $24.9 \pm 0.1$ & $24.9 \pm 0.1$ & $24.9 \pm 0.1$ & $24.9 \pm 0.1$ & $24.8 \pm 0.2$ \\
\hline \multirow[t]{4}{*}{ P. mirabilis } & 1 & $10 \pm 0$ & $12.3 \pm 0.6$ & $11.3 \pm 0.6$ & $10 \pm 0$ & $11.3 \pm 1.2$ & $10 \pm 0$ & $13.3 \pm 1.2$ & $12.7 \pm 1.2$ & $10.7 \pm 1.2$ & $16 \pm 1.7$ & $10 \pm 0$ & $10.7 \pm 1.2$ & $16 \pm 0$ & $16.7 \pm 1.2$ & $14.7 \pm 0.6$ \\
\hline & $1 / 2$ & $12.7 \pm 0.6$ & $12.3 \pm 2.5$ & $10.7 \pm 1.2$ & $14.3 \pm 1.2$ & $12.3 \pm 1.5$ & $17.7 \pm 0.6$ & $15 \pm 0$ & $15.7 \pm 1.2$ & $13 \pm 1.7$ & $14.3 \pm 1.2$ & $7 \pm 0.6$ & & $12 \pm 2$ & $3.3 \pm 1.5$ & $13 \pm 1.7$ \\
\hline & $1 / 3$ & $13 \pm 1$ & $13.7 \pm 0.6$ & $10.3 \pm 0.6$ & $13 \pm 1.7$ & $12.7 \pm 1.2$ & $14 \pm 1$ & $17.7 \pm 0.6$ & $13.3 \pm 0.6$ & $16 \pm 1$ & $12 \pm 2.7$ & $12.7 \pm 1.2$ & $14.3 \pm 1.2$ & $13.3 \pm 1.5$ & $12 \pm 2$ & $14 \pm 1$ \\
\hline & GEN & $27.9 \pm 0.1$ & $27.9 \pm 0.1$ & $27.9 \pm 0.1$ & $27.9 \pm 0.1$ & $27.9 \pm 0.1$ & $27.9 \pm 0.1$ & $27.9 \pm 0.1$ & $27.9 \pm 0.1$ & $27.9 \pm 0.1$ & $27.9 \pm 0.1$ & $27.9 \pm 0.1$ & $27.9 \pm 0.1$ & $27.9 \pm 0.1$ & $27.9 \pm 0.1$ & $28.5 \pm 0.4$ \\
\hline \multirow[t]{4}{*}{ S. marcescens } & 1 & $15 \pm 0$ & $11.3 \pm 1.2$ & $11.3 \pm 1.2$ & $13 \pm 0$ & $10.7 \pm 1.2$ & $12 \pm 0$ & $11.7 \pm 1.5$ & $10.3 \pm 0.6$ & $15.7 \pm 1.2$ & $11.3 \pm 1.2$ & $12 \pm 0$ & $11.7 \pm 0.6$ & $13.7 \pm 1.5$ & $15 \pm 0$ & $13 \pm 0$ \\
\hline & $1 / 2$ & $10 \pm 0$ & $10 \pm 0$ & $10 \pm 0$ & $10.7 \pm 1.2$ & $10 \pm 0$ & $11 \pm 1$ & $10 \pm 0$ & $10 \pm 0$ & $10 \pm 0$ & $10.3 \pm 0.6$ & $10.3 \pm 0.6$ & $10.7 \pm 0.6$ & $10.7 \pm 1.2$ & $10.7 \pm 1.2$ & $11.7 \pm 1.5$ \\
\hline & $1 / 3$ & $10.7 \pm 1.2$ & $8.3 \pm 0.6$ & $8 \pm 0$ & $10.3 \pm 0.6$ & $10 \pm 0$ & $9.3 \pm 1.2$ & $10 \pm 0$ & $10.3 \pm 0.6$ & $11 \pm 1$ & $10.8 \pm 0.6$ & $10 \pm 0$ & $10 \pm 0$ & $12 \pm 0$ & $10 \pm 0$ & $10.7 \pm 1.2$ \\
\hline & GEN & $23.9 \pm 0.1$ & $27.9 \pm 0.1$ & $23.9 \pm 0.1$ & $23.9 \pm 0.1$ & $23.9 \pm 0.1$ & $23.9 \pm 0.1$ & $23.9 \pm 0.1$ & $23.9 \pm 0.1$ & $23.9 \pm 0.1$ & $23.9 \pm 0.1$ & $23.9 \pm 0.1$ & $23.9 \pm 0.1$ & $23.9 \pm 0.1$ & $23.9 \pm 0.1$ & $24.5 \pm 0.5$ \\
\hline \multirow[t]{4}{*}{ S. liquefacienes } & 1 & $11.3 \pm 1.2$ & $11.3 \pm 1.2$ & $10.7 \pm 1.2$ & $13.3 \pm 0.6$ & $13.3 \pm 1.2$ & $13 \pm 0$ & $12 \pm 1$ & $14 \pm 1$ & $13.3 \pm 1.2$ & $12.3 \pm 0.6$ & $12 \pm 0$ & $15 \pm 0$ & $13.3 \pm 1.2$ & $16.7 \pm 1.5$ & $10 \pm 0$ \\
\hline & $1 / 2$ & $10.7 \pm 0.6$ & $10 \pm 0$ & $10.3 \pm 0.6$ & $12.7 \pm 0.6$ & $12 \pm 0$ & $11 \pm 1$ & $11.3 \pm 1.2$ & $10 \pm 0$ & $12.3 \pm 0.6$ & $10 \pm 0$ & $10 \pm 0$ & $13 \pm 0$ & $12.3 \pm 0.6$ & $15 \pm 0$ & $8 \pm 0$ \\
\hline & $1 / 3$ & $10.7 \pm 1.2$ & $10.7 \pm 1.2$ & $10 \pm 0$ & $11.3 \pm 1.2$ & $10.7 \pm 0.6$ & $10.3 \pm 0.6$ & $11 \pm 0$ & $12.3 \pm 0.6$ & $10.7 \pm 1.2$ & $10.7 \pm 0.6$ & $11.3 \pm 1.2$ & $13 \pm 0$ & $10 \pm 0$ & $11.3 \pm 1.2$ & $8 \pm 0$ \\
\hline & GEN & $17.9 \pm 0.1$ & $17.9 \pm 0.1$ & $17.9 \pm 0.1$ & $17.9 \pm 0.1$ & $17.9 \pm 0.1$ & $17.9 \pm 0.1$ & $17.9 \pm 0.1$ & $17.9 \pm 0.1$ & $17.9 \pm 0.1$ & $17.9 \pm 0.1$ & $17.9 \pm 0.1$ & $17.9 \pm 0.1$ & $17.9 \pm 0.1$ & $17.9 \pm 0.1$ & $17.9 \pm 0.1$ \\
\hline \multirow[t]{4}{*}{ E. cloacae } & 1 & $20 \pm 0$ & $15 \pm 5$ & $16.7 \pm 2.9$ & $18.3 \pm 2.9$ & $10 \pm 0$ & $25 \pm 0$ & $14.3 \pm 0.6$ & $14.3 \pm 1.2$ & $16.3 \pm 1.5$ & $13.7 \pm 1.2$ & $19.3 \pm 1.2$ & $13.7 \pm 1.2$ & $17.3 \pm 1.2$ & $10.3 \pm 0$ & $15.7 \pm 1.2$ \\
\hline & $1 / 2$ & $18.7 \pm 1.2$ & $10.3 \pm 0.6$ & $11.7 \pm 0.6$ & $10 \pm 0$ & $14.7 \pm 0.6$ & $16.7 \pm 2.9$ & $11 \pm 0$ & $13.7 \pm 1.2$ & $10 \pm 0$ & $12.7 \pm 0.6$ & $12.3 \pm 1.2$ & $11 \pm 1$ & $11.7 \pm 1.5$ & $12.7 \pm 0$ & $11.3 \pm 0.6$ \\
\hline & $1 / 3$ & $11.7 \pm 2.9$ & $10 \pm 0$ & $10.7 \pm 1.2$ & $10 \pm 0$ & $10.3 \pm 0.6$ & 110 & $10 \pm 0$ & $10.3 \pm 0.6$ & $8 \pm 0$ & $10.7 \pm 0.6$ & $10 \pm 0$ & $11.3 \pm 1.2$ & $10.3 \pm 0.6$ & $8.7 \pm 1.2$ & $10.3 \pm 0.6$ \\
\hline & GEN & $19.9 \pm 0.1$ & $19.9 \pm 0.1$ & $19.9 \pm 0.1$ & $19.9 \pm 0.1$ & $19.9 \pm 0.1$ & 19.90 .1 & $19.9 \pm 0.1$ & $19.9 \pm 0.1$ & $19.9 \pm 0.1$ & $19.9 \pm 0.1$ & $19.9 \pm 0.1$ & $19.9 \pm 0.1$ & $19.9 \pm 0.1$ & $19.9 \pm 0.1$ & $19.9 \pm 0.1$ \\
\hline
\end{tabular}




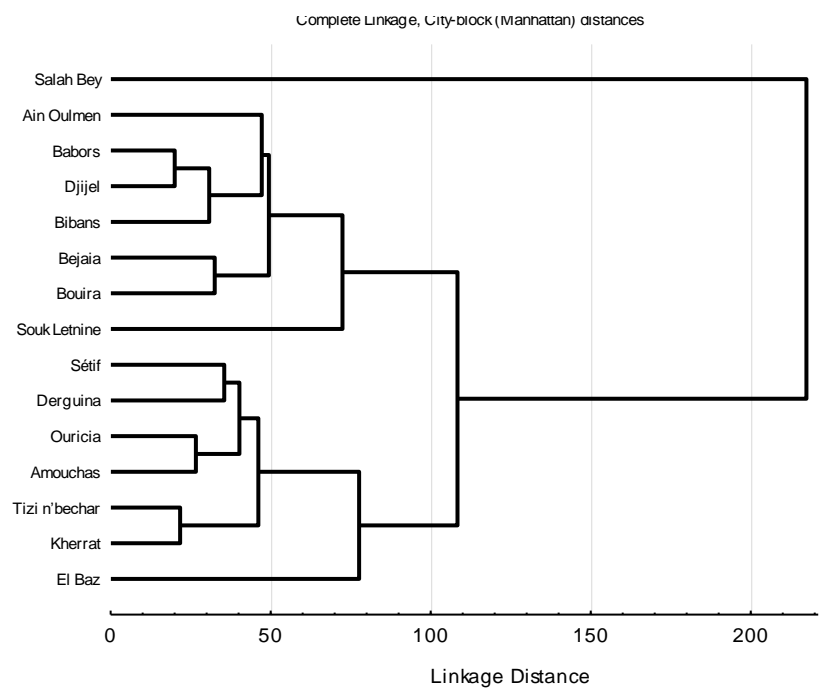

Figure 6. Relationships among Inula viscosa populations based on the chemical composition

Table 5. Main effects and interactions of essential oils of Inula viscosa

\begin{tabular}{llll}
\hline Sources & df & $\mathbf{F}$ & $\mathbf{p}$ \\
\hline Main effects & & & \\
Sampling locations & 14 & 45 & $.000 * * *$ \\
Dilution level & 3 & 41147 & $.000 * * *$ \\
Species of bacteria & 14 & 4269 & $.000 * * *$ \\
Interaction & & & \\
Sampling locations * Dilution level & 42 & 20 & $.000 * * *$ \\
Sampling locations * Bacteria & 196 & 45 & $.000 * * *$ \\
Dilution level * Bacteria & 42 & 1216 & $.000 * * *$ \\
Sampling locations * Dilution level * & 588 & 16 & $.000 * * *$ \\
Bacteria & & & \\
\hline
\end{tabular}

Table 6. The effectiveness of Inula viscosa essential oils from several sampling locations against eight bacteria species

\begin{tabular}{|c|c|c|c|c|}
\hline Rank & $\begin{array}{l}\text { Sampling } \\
\text { locations }\end{array}$ & $\begin{array}{c}\text { Mean inhibition } \\
\text { zone (mm) }\end{array}$ & $\mathbf{n}$ & $\begin{array}{c}\text { Significant } \\
\text { groups }\end{array}$ \\
\hline 1 & Setif & 18.72 & $180 \mathrm{a}$ & \\
\hline 2 & Ain Oulmene & 18.55 & $180 \mathrm{a}$ & \\
\hline 3 & Ouricia & 18.30 & 180 & $\mathrm{~b}$ \\
\hline 4 & Jijel & 18.21 & 180 & $\mathrm{~b}$ \\
\hline 5 & El Bez & 18.15 & 180 & $\mathrm{~b}$ \\
\hline 6 & Bejaia & 18.14 & 180 & $\mathrm{~b}$ \\
\hline 7 & Souk Letnine & 17.92 & 180 & $\mathrm{c}$ \\
\hline 8 & Biban & 17.83 & 180 & cd \\
\hline 9 & Babor & 17.70 & 180 & de \\
\hline 10 & Tizi n'Bechar & 17.64 & 180 & ef \\
\hline 11 & Bouira & 17.59 & 180 & ef \\
\hline 12 & Derguina & 17.54 & 180 & ef \\
\hline 13 & Saleh Bey & 17.53 & 180 & ef \\
\hline 14 & Kherrata & 17.51 & 180 & $\mathrm{f}$ \\
\hline 15 & Amouchas & 17.19 & 180 & \\
\hline
\end{tabular}

Note: LSD $0.05=0.17943458234$

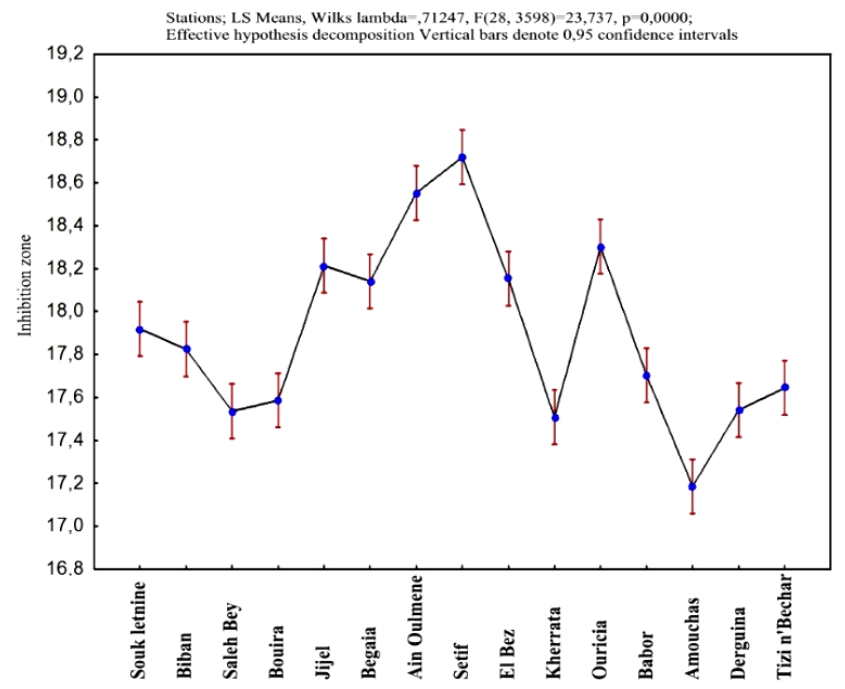

Figure 7. Effective hypothesis decomposition of Inula viscosa populations

Table 7. Effect of oil dilutions on the inhibitory zone of bacteria tested

\begin{tabular}{llccllll}
\hline Rank & $\begin{array}{c}\text { Dilution } \\
\text { level }\end{array}$ & $\begin{array}{c}\text { Mean inhibition } \\
\text { zone }(\mathbf{m m})\end{array}$ & \multicolumn{2}{c}{ n } & \multicolumn{2}{c}{ Significant groups } \\
\hline 1 & Gentamicin & 27.80 & 675 & $\mathrm{a}$ & & & \\
2 & $1 / 1$ & 16.74 & 675 & & $\mathrm{~b}$ & & \\
3 & $1 / 2$ & 13.99 & 675 & & & $\mathrm{c}$ & \\
4 & $1 / 3$ & 13.08 & 675 & & & $\mathrm{~d}$ \\
\hline
\end{tabular}

Note: LSD $0.05=0.09265961989$

The three-way analysis of variance revealed a very significant difference in the diameters of the inhibitory zones among the essential oils dilutions. Gentamicin has the highest growth inhibition against several bacteria tested with an average inhibitory zone of $27.80 \mathrm{~mm}$. It is classified in group (a) (Table 7). The antibacterial activity of the diluted essential oils (1/2 and 1/3) was a weak activity, with a diameter of growth inhibition of 13.99$13.08 \mathrm{~mm}$.

The results reveal that $S$. aureus is highly sensitive to the essential oils of $I$. viscosa. It is classified in group (a), with an average diameter of growth inhibition of $26.84 \mathrm{~mm}$ (Table 8), while E. faecalis and S. liquefaciens were the least sensitive to $I$. viscosa oils, with an average diameter of growth inhibition of 13.30 to $13.18 \mathrm{~mm}$.

\section{Desirability test}

The relationship between predicted responses on one or more dependent variables and the desirability of responses is called the desirability function. Profiling the desirability of the responses involves first, specifying the desirability function for each dependent variable, by assigning predicted values a score ranging from 0 (very undesirable) to 1 (very desirable). The optimal parameters of this study were located in the exact region of the central point (Figure 
8). The desirability profile of I. viscosa essential oils against the bacteria tested had a prediction value of 0.28584 , which is considered a low value. The oil prediction value of the populations is low, except for the oil of the Souk Letnine population that has a value greater than 0.28584 . The dilutions of the oils used in this study have a low activity against the bacteria tested; they have a equal values than the prediction value; on the other hand gentamicin is more effective in inhibiting bacteria than $I$. viscosa essential oils. The desirability test shows that the bacterial species are sensitive to the oils of Inula viscose, with prediction values greater than 0.2584 .

Table 8. Sensitivity groups of the bacteria tested to the essential oils of Inula viscosa

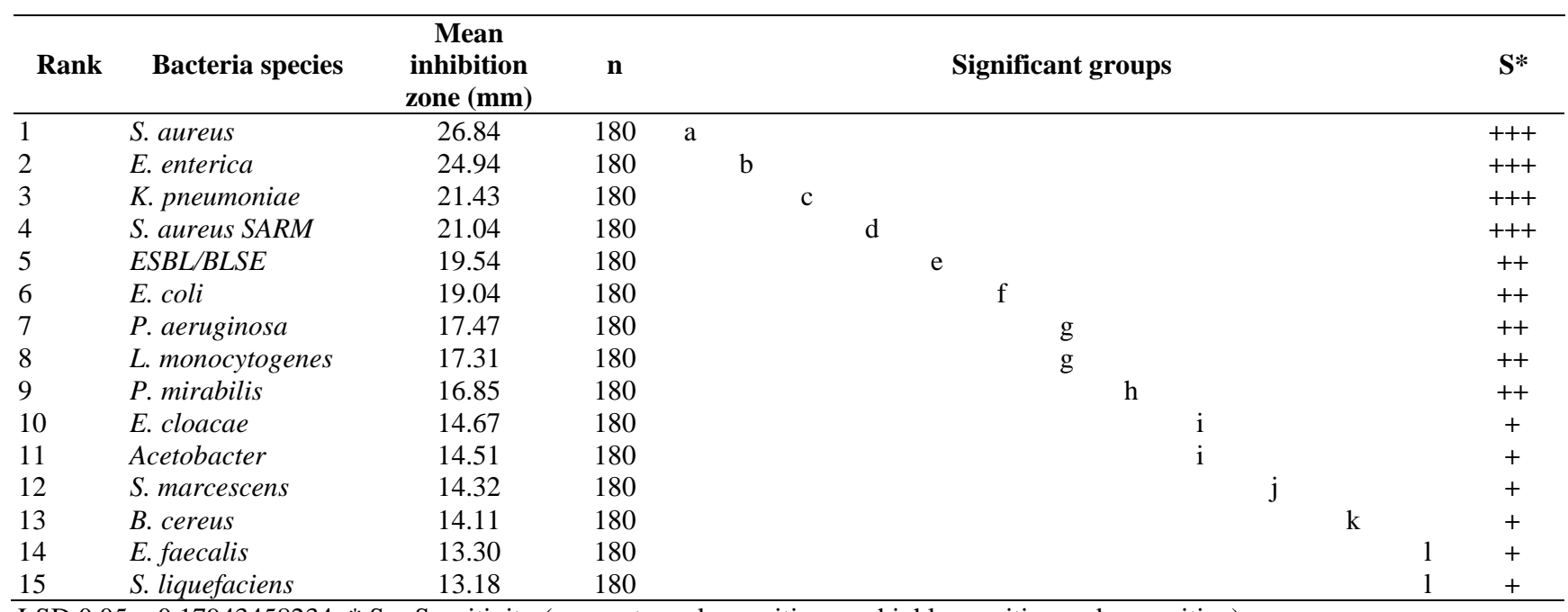

LSD $0.05=0.17943458234 ; * \mathrm{~S}=$ Sensitivity (+++ extremely sensitive, ++ highly sensitive and + sensitive)

Profiles for Predicted Values and Desirability

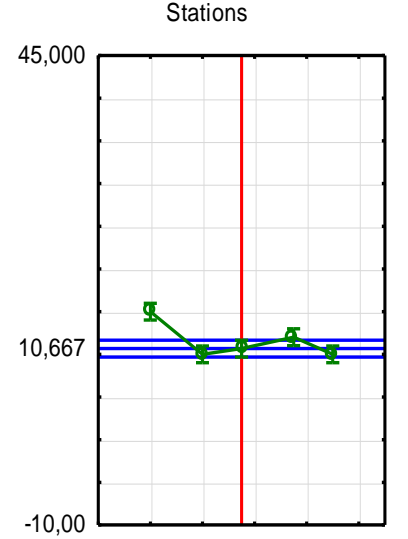

Dilution levels

Bateria
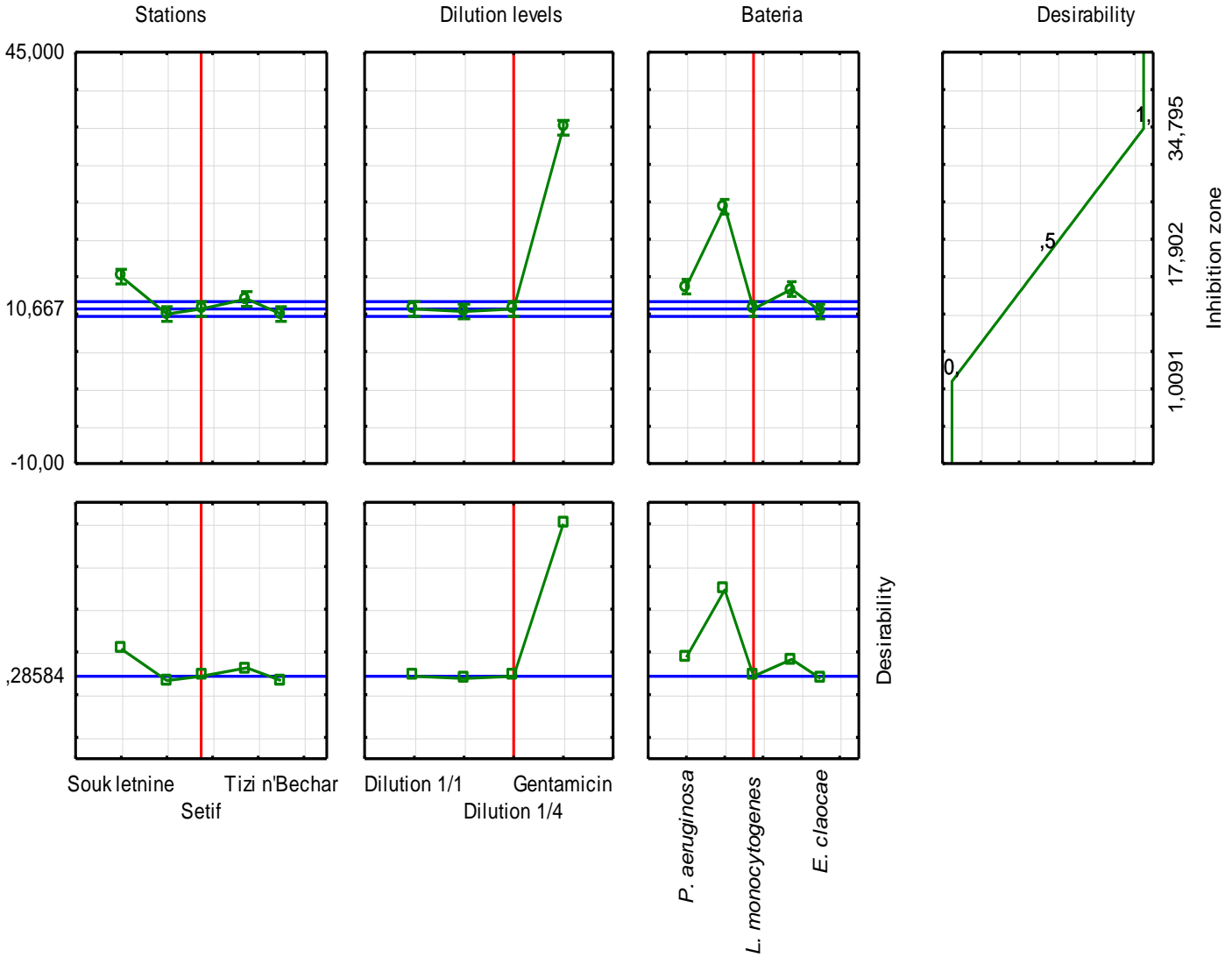

Figure 8. Profile of Predicted Values and Desirability for the inhibition zones induced by Inula viscosa essential oils against bacteria 
Complete Linkage, City-block (Manhattan) distances

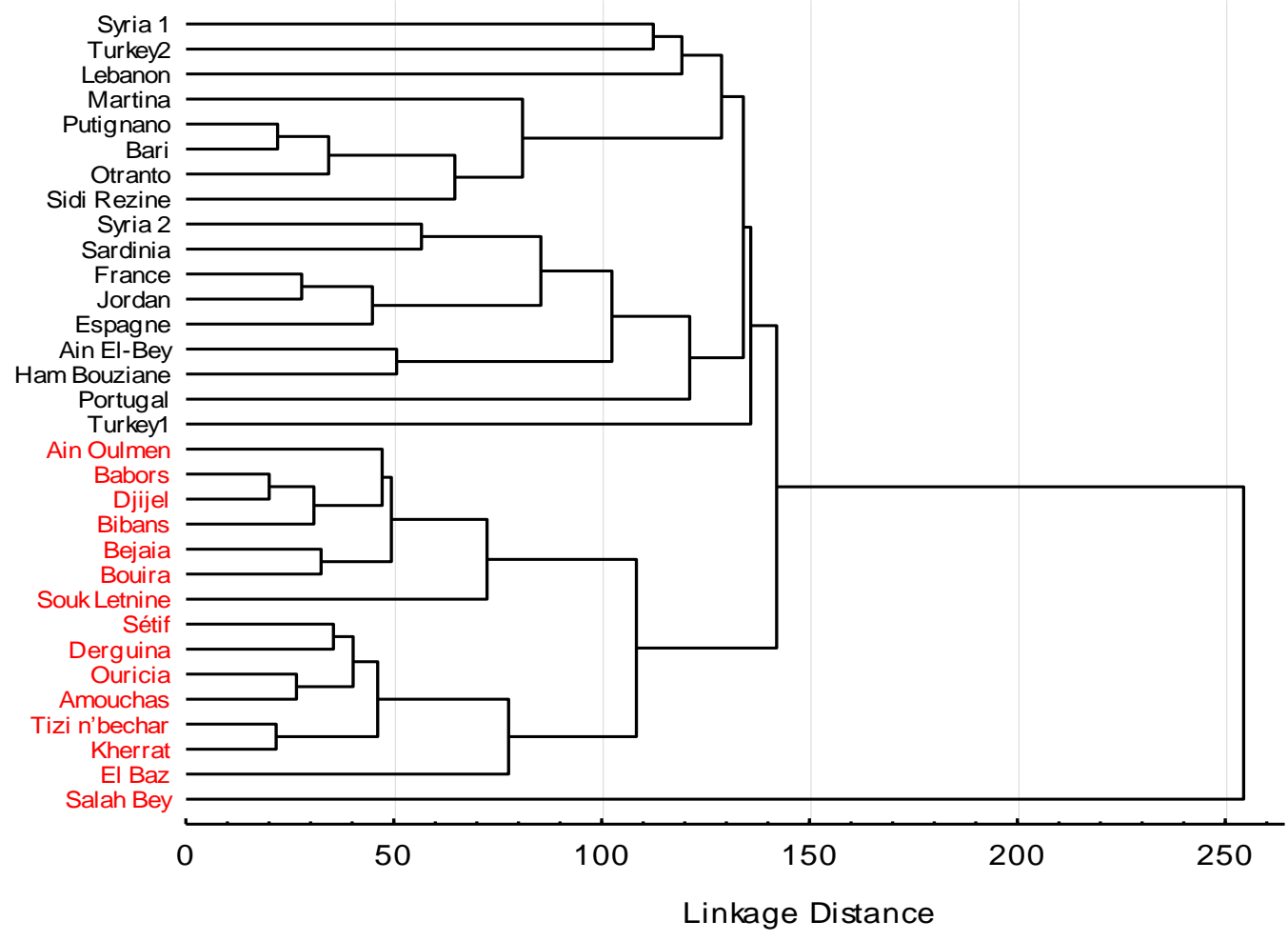

Figure 9. Relationships among Inula viscosa populations in the world

\section{Discussion}

The essential oils of Inula viscosa obtained by hydrodistillation have very low yields with an average of $0.23 \pm$ $0.06 \%$. A study by Boudouda et al. (2012) showed that the yield of I. viscosa essential oils ranged from 8 to $10 \%$ (obtained by solvant extractions). On the other hand, the yields of I. viscosa essential oils obtained from Sidi Rezine (Algeria) was $0.34 \%$ (Madani et al. 2014). In the same region, Haoui et al. (2015) found a yield ranging from 0.15 to $0.45 \%$. The yields obtained by De Laurentis et al. (2002) from different regions of Apulia (Italy), vary between 0.35 and $0.37 \%$, depending on the part of the plant.

The aerial parts (Leaves and flowers) of I. viscosa growing wild in Al-Qadmous (Syria), gave an essential oil yield of $0.10 \%$ and $0.09 \%$, respectively (Nasser et al. 2014). The aerial parts of Kafr Hoor (Syria) gave an essential oil yield of $0.17 \%$ (Alalan et al. 2015). The yields of oils from mountainous and coastal regions from Lattakia (Syria) were (0.67-0.55\%) (Hwija et al. 2018). The populations from Irbid (Jordan) gave a yield of $0.05 \%$ (AlQudah et al. 2010).

Chromatographic analysis of I. viscosa oils revealed that polygodial and phytol were the major components with an average of $19.8 \pm 16.9$ and $12.3 \pm 9.77 \%$ respectively. However, phytol, which is poorly represented in Algiers populations (Haoui et al. 2011) and in Italy (De Laurentiis et al. 2002) is predominant in the oils of Jijel and Setif populations.

The chemical composition of I. viscosa essential oils in this study is different from that which has been analyzed previously, from Ain Elbey and Hama Bouziane (Algeria)
(Boudouda et al. 2012). These populations are characterized by the presence of $\beta$-caryophyllene, intermediol neo and isocostic acid, while the latter compound is absent from the oils of our populations. The Oran population is characterized by the presence of $\alpha$-terpineol (Boumaza 2011) which is present in our populations at a very low content with an average of $0.42 \pm 0.5 \%$. Fokienol, the major component of Jordan populations (Al-Qudah 2010), is present in our populations with an average of $6.01 \pm 3.43 \%$. Borneol which is very weakly present in the populations studied, is present with important concentrations in the populations of Turkey (Haoui et al. 2011).

Comparison of the chemical components of I. viscosa populations, using the UPGMA analysis (Figure 9), shows that the populations are subdivided into two clades. The first clade is represented by the population of Saleh Bey with a very high polygonal percentage $(58.7 \%)$. The second clade is subdivided into two groups. The first one brings together the populations studied, while the second group brings together the rest of the world populations, including the Algerian populations, studied by Haoui et al. (2011) and Boudouda et al. (2012).

The differences in the chemical composition of the same species are probably due to various parameters, including the environment, geographic origin, and harvest period (Aboukhalid et al. 2017; Yeddes et al. 2018).

The antibacterial test showed that $S$. aureus was the most sensitive to the essential oil of I. viscosa, while $E$. faecalis and $S$. liquefaciens were the most resistant to oils from the 15 populations of this study. These results are consistent with the conclusions of Boudouda et al. (2012) 
who have shown that $K$. pneumoniae, $P$. aeruginosa exhibited a good antibacterial activity and that E. coli was resistant to methanolic extracts of $I$. viscosa. The Staphylococcus aureus and Enterobacter sp. strains are rated sensitive, while Escherichia coli, Bacillus thuringiensis, Pseudomonas aeruginosa, Micrococcus sp. are mildly sensitive (Chebouti-Meziou 2016).

In conclusion, the essential oils of I. viscosa collected from 15 locations in Algeria have chemical compositions different from those described in the literature. GC/MS analysis lead to the identification of 42 components in the essential oil. The main components were polygodial, phytol, fokienol, intermedeol-neo, caryophyllene oxide, nerolidol-Z, nerolidol-E, and $\alpha$-ionone iso methyl-E. The chemical composition of $I$. viscosa populations showed a notable difference with an abundance of hydrocarbon monoterpenes. This difference allowed us to identify five chemotypes Polygodial-Intermedeol neo-Phytol, two chemotypes with Fokinol-Polygodial and two other with Fokinol-Phytol. The bacterial species tested were sensitive to the essential oils of I. viscosa. The optimal inhibition of I. viscosa essential oils was obtained with undiluted oils of Setif and Ain Oulmene populations on the S. aureus bacterium. Optimization was confirmed by the desirability parameter, which attained a low value, though acceptable.

\section{ACKNOWLEDGEMENTS}

The work was supported by Algerian MESRS (Ministry of higher education and scientific research) and LEXVA Analytique, France.

\section{REFERENCES}

Aboukhalid K, Al Faiz C, Douaik A, Bakha M, Kursa K, AgackaMołdoch M, Machon N, Tomi F, Lamiri A. 2017. Influence of environmental factors on essential oil variability in Origanum compactum Benth. growing wild in Morocco. Chem Biodivers 14 (9): e1700158. DOI: $10.1002 / \mathrm{cbdv} .201700158$.

Adams RP. 2007. Identification of essential oils components by Gas Chromatography-Mass spectroscopy. Allured Publishing Corporation Carol Stream, Illinois USA

Aissa I, Znati M, Zardi Bergaoui A, Flamini G, Ascrizzi R, Ben Jannet H. 2019. GC and GC-MS integrated analyses and in vitro antibacterial, anticholinesterase, anti-tyrosinase, and anti-5-lipoxygenase potential of Inula viscosa root fractionated essential oil. S Afr J Bot 125: 386392. DOI: 10.1016/j.sajb.2019.08.019.

Akkawi M, Abbas I, Jaber S, Aburemeleh Q, Naseredin A, Lutgen P. 2014. Investigation of Traditional Palestinian Medicinal Plant Inula viscosa as Potential Anti-malarial Agent. Br J Pharmacol Toxicol 5 (5): $156-162$.

Alalan L, AL-Shammaa I, Al-Nouri AS. 2015. Analysis of the chemical composition of essential oil extracted from Syrian Inula viscosa (L). Chem Pharm Res 7 (12): 861-864.

Alkofahi A, Atta AH. 1999. Pharmacological screening of the antiulcerogenic effects of some Jordanian medicinal plants in rats. J Ethnopharmacol 67: 341-345. DOI: 10.1016/s0378-8741 (98)00126-3

Al-Masri MI, Sharawi SM, Barakat RM. 2015. Effect of clammy inula (Inula viscose) plant extract in combination with a low dose of the fungicide iprodione on Botrytis cinerea in vitro and in vivo. Am J Plant Sci 6 (9): 1519.

Al-Qudah MA, Al-Jaber HI, Mayyas AS, Abu-Orabi ST, Abuzarga MH. 2010. Chemical compositions of essential oil from the Jordanian Medicinal plant Dittrichia viscosa. Jordan J Chem 5: 343-348.
Amin S, Kaloo ZA, Singh S, Altaf T. 2013. Medicinal importance of genus Inula-A Review. Intl J Curr Res Rev 5 (2): 20-26.

Andolfi A, Zermane N, Cimmino A, Avolio F, Boari A, Vurro M, Evidente A. 2013. Inuloxins A-D, phytotoxic bi-and tri-cyclic sesquiterpene lactones produced by Inula viscosa: Potential for broomrapes and field dodder management. Phytochemistry 86: 112120.

Assi M, Aboul-Ela MA, Ellakany AM, Abdul-Ghani M. 2014. A comparative phytochemical and antimicrobial analysis of Inula viscosa and Inula crithmoides grown in Lebanon. Acad J Med Plants 2 (4): 057-067. DOI: 10.15413/ajmp.2013.0122.

Bar-Shalom R, Bergman M, Graossman S, Azzam N, Sharvit L, Fares F. 2019. Inula viscosa extract inhibits growth of colorectal cancer cells in vitro and in vivo through induction of apoptosis. Front Oncol 9: 227.

Belayachi L, Aceves-Luquero C, Merghoub N, Bakri Y, Fernández de Mattos S, Amzazi Sand PV. 2013. Screening of North African medicinal plant extracts for cytotoxic activity against tumor cell lines. Eur J Med Plants 3 (3): 310-332.

Bensassi A, Harzallah-Skhiri F, Bourgougnon N, Aouni M. 2008. Antiviral activity of some Tunisian medicinal plants against Herpes simplex virus type 1. Nat Prod Res 22 (1): 53-65. DOI: 10.1080/14786410701589790.

Benseguini-Tounsi L. 2001. Etude in vitro de l'effet antibactérien et antifongiques d'Inula viscosa, Lawsonia inermis, Asphodelus microcarpus, Aloe vera et Juniperus oxycedrus. Mémoire de magistère en médecine vétérinaire. Université de Constantine, Algerie. [France]

Blanc MC, Bradesi P, Gonçalves MJ, Salgueiro L, Casanova J. 2006. Essential oil of Dittrichia viscosa spp. viscosa: analysis by $168 \mathrm{C}$ NMR and antimicrobial activity. Flavour Fragr J 21: 324-332. DOI: $10.1002 /$ ffj. 1605

Boudouda HB, Benmerache A, Chibani S, Kabouche A, Abuhamdah S, Semra Z, Kabouche Z. 2012. Antibacterial activity and chemical composition of essential oils of Inula viscosa (L.) Ait. (Asteraceae) from Constantine, Algeria. Pharm Lett 4: 1863-1867.

Boudouda HB. 2014. Etude phytochimique et biologique des espèces Biscutella raphanifolia, Zilla macroptera, Inula graveolens et Inula viscosa. [Thèse Doctorat troisème cycle (LMD)] Université de Constantine 1, Algerie. [France]

Boumaza D. 2011. Séparation et caractérisation chimique de quelque biomolécules actives de deux plantes médicinales : Inula viscosa et Rosmarinus officinalis de la région d'Oran. [Thèse de Magister] Université d'Oran, Algerie. [France]

Bouyahya A, Et-Touys A, Khouchlaa A, El-Baaboua A, Benjouad A, Amzazi S, Dakka N, Bakri Y. 2018. Ethnobotanical and Phytopharmacological Notes on Inula viscosa. Phytotherapy 16 (S1): S263-S268. DOI: 10.3166/s10298-017-1176-2.

Brullo S, De Marco G. 2000. Taxonomical revision of the genus Dittrichia (Asteraceae). Portugaliae Acta Biol 19: 341-354

Bssaibiss F, Gmira N, Meziane M. 2009. Les plantes médicinales et aromatiques. Rev Microbiol Ind San et Environ 3 (1): 44-55. [France]

Cafarchia C, De Laurentis N, Milillo MA, Losacco V. 2002. Antifungal activity of oils leaves and flowers of Inula viscosa (Asteraceae) by Apulian region. Parasitologia 44: 153-156.

Camacho A, Fernández A, Fernández C, Altarejos J, Laurent R. 2000. Composition of the essential oil of Dittrichia viscosa (L.). W. Greuter. Riv. Ital. EPPOS. 29: 3-8

Chahmi N, Anissi J, Jennan S, Farah A, Sendide K, El Hassouni M. 2015. Antioxidant activities and total phenol content of Inula viscosa extract selected from three regions of Morocco. Asian Pac J Trop Biomed 5 (3): 228-233.

Chebouti-Meziou N. 2016. Contributions to Study of the Antimicrobial Activity of Inula viscosa Harvested in Boumerdes (Algeria). J Adv Chem Eng Biol Sci 3 (1): 159-162. DOI: 10.15242/IJACEBS.C0516204.

Chiarlo B. 1968. Sui costituenti dell'Inula viscosa Ait. Contenuto in azuleni dell'olio essenziale. Boll Chim Farm 107 (6): 370-382.

Cohen Y, Baider A, Ben-Daniel BH, Ben-Daniel Y. 2002. Fungicidal preparations from Inula viscosa. Plant Prot Sci 38: 629-630.

Dahiya P, Purkayastha S. 2012. Phytochemical screening and antimicrobial activity of some medicinal plants against multi-drug resistant bacteria from clinical isolates. Indian J Pharm Sci 74 (5): 443-450. DOI: 10.4103/0250-474X.108420.

De Laurentis N, Losacco V, Milillo M, Lai O. 2002. Chemical investigations, of volatile constituents of Inula viscosa (L.) Aiton 
(Asteraceae) from different areas of Apulia. Southern Italy. Delpinoa, n.s. 44: 115-119.

Franco-Mican SX, Castro J, Campos M. 2008. Observation du complexe parasitaire de l'inule visqueuse en Espagne et ses méthodes de propagation. Le Nouvel Olivier. $n^{\circ} 66$. Nov. déc. [France]

Gharred N, Dbeibia A, Falconieri D, Hammami S, Piras A, Dridi Dhaouadi S. 2019. Chemical composition, antibacterial and antioxidant activities of essential oils from flowers, leaves and aeria parts of Tunisian Dittrichia viscosa. J Essent Oil Res 31 (6): 582-589.

Haoui IE, Derriche R, Madani L, Oukali Z. 2011. Analysis of the chemical composition of essential oil from Algerian Inula viscosa L., Arabian J Chem 21 (14): 587-590 DOI: 10.1016/j.arabjc.2011.05.005

Haoui IE, Derrichea R, Madania L, Oukalib Z. 2015. Analysis of the chemical composition of essential oil from Algerian Inula viscosa (L.) Aiton. Arabian J Chem 8 (4): 587-590. DOI: 10.1016/j.arabjc.2011.05.005.

Hepokur C, Budak Y, Karayel HB, Selvi B, Yaylim I. 2019. Investigation of cytotoxic effects of Inula viscosa extract. Cumhuriyet Sci J 40 (3): 578-582. DOI: $10.17776 /$ csj. 437993.

Hwija E, Yaseer M, Mohannad H. 2018. Chemical composition of essential oils extracted from leaves of taion plant (Inula viscosa L.) from two different regions of Lattakia-Syria. Int J Novel Res Phys Chem Math 5 (1): 24-31.

Isil B, Zeynep T, Istemi S, Merve K, Tugba T, Selda M, Munevver A 2018. The negative effects of Inula viscosa L. use on cance treatment. Acta Sci Med Sci 2 (8): 19-24.

Kattouf J, Belmoukhtar M, Harnafi H, Mekhfi H, Ziyyat A, Aziz M, Bnouham M, Legssyer A. 2009. Effet antihypertenseur des feuilles d'Inula viscosa. Phytothérapie 7: 309-312. DOI 10.1007/s10298-009-0517-1. [France]

Kheyar N, Meridja D, Belhamel K. 2014. Etude de l'activité antibactérienne des huiles essentielles d'Inula viscosa, Salvia officinalis et Laurus nobilis de la région de Bejaia. Algerian J Nat Prod 2: 18-26.

Larbi KS, Meddah B, Tir Touil Meddah A, Sonnet P. 2016. The antibacterial effect of two plants Inula viscosa, Anacyclus valentinus (Asteraceae) and their synergistic interaction with antibiotic drugs. J Fundam Appl Sci 8 (2): 244-255. DOI: 10.4314/jfas.v8i2.5.

Lauro L, Rolih C. 1990. Observations and research on an extract of Inula viscosa Ait. Bollettino Societa Italiana Biological Sperimentable 66 (9): 829-834

Lev E, Amar Z. 2000. Ethnopharmacological survey of traditional drugs sold in Israel at the end of the 20th century. J Ethnopharmacol 72 (12): $191-205$

Madani L, Derriche R, Haoui IE. 2014. Essential oil of Algerian Inula viscosa leaves. J Essen Oil Bearing Plants 17 (1): 164-168.

Marongiu B, Piras A, Pani F, Porcedda S, Ballero M. 2003. Extraction separation and isolation of essential oils from natural matrices by supercritical $\mathrm{CO}_{2}$. Flavour Fragr J 18 (6): 505-509. DOI: $10.1002 / f f j .1258$

Masada Y. 1979. Analysis of Essential Oils by Gas Chromatography and Mass Spectrometry. John Wiley \& Sons, Inc., New York.

Merghoub N, Benbacer L, Amzazi S, Morjani H, El Mzibri M. 2009. Cytotoxic effect of some Moroccan medicinal plant extracts on human cervical cell lines. J Med Plants Res 3 (12): 1045-1050.

Miguel G, Faleiro L, Cavaleiro C, Salgueiro L, Casanova J. 2008 Susceptibility of Helicobacter pylori to essential oil of Dittrichic viscosa subsp. revoluta. Phytother Res: Intl J Devoted Pharmacol Toxicol Eval Nat Prod Derivatives 22 (2): 259-263.

Mohti H, Taviano MF, Cacciola F, Dugo P, Mondello L, Marino A, Crisafi G, Benameur Q, Zaid A, Miceli N. 2019. Inula viscosa (L.) Aiton leaves and flower buds: effect of extraction solvent/technique on their antioxidant ability, antimicrobial properties and phenolic profile. J Nat Prod Res (Formerly Nat Prod Lett) 1: 1-7. DOI 10.1080/14786419.2019.1569659.

Nasser M, Housheh S, Kourini A, Maala N. 2014. Chemical composition of essential oil from leaves and flowers of Inula viscosa (L.) in Alqadmous region Syria. Intl J Pharmaceut Sci Res 5 (12): 5177-5182. DOI: 10.13040/IJPSR.0975-8232.5 (12).5177-82

NIST. 2002. Mass Spectral Search Program for the NIST/EPA/NIH Mass Spectral Library, vers. 2.0. fiveash data, USA.

Ozkan E, Karakas FP, Yildirim AB, Tas D, Eker D, Yavuz MZ, Türker AU. 2019. Promising medicinal plant Inula viscosa L.
Antiproliferative, antioxidant, antibacterial and phenolic profiles. Prog Nutr 21 (3): 652-661. DOI: 10.23751/pn.v21i3.7186.

Parolin P, Scotta M, Bresch C. 2014. Biology of Dittrichia viscosa a Mediterranean ruderal plant. Int J Exp Bot 83 (2): 251-261.

Perez-Alonso MJ, Velasco-Negueruela A, Emin-Duru M, Garcia Vallejo MC. 1996. Composition of the volatile oil from the Aerial parts of Inula viscosa (L.) Aiton. Flavour Fragr J 11: 349-351.

Pistelli L, Bandeira Reidel RV, Parri F, Morelli E, Pistelli L. 2019. Chemical composition of essential oil from plants of abandoned mining sites of Elba island. Nat Prod Res 33 (1): 143-147.

Ponce AG, Fritz R, Del Valle C, Roura SI. 2003. Antimicrobial activity of essential oils on the native microflora of organic Swiss chard. Lebensmittel-Wissenschaft und Technologie 36 (7): 679-684. DOI: 10.1016/S0023-6438 (03)00088-4

Prisa D. 2019. Possible use of Inula viscosa (Dittrichia viscosa L.) for biostimulation of Oscularia deltoids and Corpuscolaria lehmanii plants and protection against Aphis nerii. GSC Biol Pharm Sci 9 (3): 69-75. DOI: 10.30574/gscbps.2019.9.3.0231.

Quézel P, Santa S. 1962. Nouvelle Flore de l'Algérie et des régions désertiques Méridionales. Paris. [France]

Rajkumar R. 2012. Community Based Cancer Screening-The 12 "I"s Strategy for Success. Topics on Cervical Cancer with an Advocacy for Prevention. IntechOpen, London.

Remli B. 2013. Extraction des flavoniodes de la plante Inula viscusa de la région d'Oran et mise en evidence de l'activité microbienne. Mémoire de magistère en chimie. Université d'Oran, Algerie. [France]

Rhimi W, Ben Salem I, Immediato D, Saidi M, Boulila A, Cafarchia C. 2017. Chemical composition, antibacterial and antifungal activities of crude Dittrichia viscosa (L.) greuter leaf extracts. Molecules 22 (7): 942.

Rhimi W, Salem IB, Iatta R, Chaabane H, Saidi M, Boulila A, Cafarchia, C. 2018. Dittrichia viscosa L. leaves lipid extract: An unexploited source of essential fatty acids and tocopherols with antifungal and anti-inflammatory properties. Ind Crops Prod 113: 196-201.

Rozenblat S, Grossman S, Bergman M, Gottlieb H, Cohen Y, Dovrat S. 2008. Induction of G2/M arrest and apoptosis by sesquiterpene lactones in humain melanoma cell lines. Biochem Pharmacol 75: 369382. DOI: $10.1016 /$ j.bcp.2007.08.024.

Schinella GR, Tournier HA, Prieto JM, Mordujovich de Buschiazzo P, Rios JL. 2002. Antioxidant activity of anti-inflammatory plant extracts. Life Sci 70 (9): 1023-1033. DOI: 10.1016/s0024-3205 (01)01482-5.

Seca AML, Grigore A, Pinto D, Silva AMS. 2014. The genus Inula and their metabolites: From ethnopharmacological to medicinal uses. J Ethnopharmacol 154 (2): 286-310. DOI: 10.1016/j.jep.2014.04.010.

Sevindik E, Paksoy MY. 2017. Evaluation of essential oil composition Genus Dittrichia L. (Asteraceae) Plants in Aydın/Turkey. Türk Tarım ve Doğa Bilimleri Dergisi 4 (4): 456-460.

Silva D, Denham E, Faleiro L, Miguel G, Cavaleiro C, Salgueiro L. 2005. Antimicrobial activity of the essential oils of Dittrichia viscosa subsp. viscosa on Helicobacter pylori. Acta Hortic 680 (680): 147-151. DOI: 10.17660/ActaHortic.2005.680.22

Sriti Eljazi J, Selmi S, Zarroug Y, Wesleti I, Aouini B, Jallouli S, Limam F. 2018. Essential oil composition, phenolic compound, and antioxidant potential of Inula viscosa as affected by extraction process. Intl J Food Prop 21 (1): 2309-2319.

Talib WH, Abu Zarga MH, Mahasneh AM. 2012. Antiproliferative. antimicrobial and apoptosis inducing effects of compounds isolated from Inula viscosa. Molecules 17 (3): 3291-3303. DOI: 10.3390/molecules17033291.

Yeddes W, Wannes WA, Hammami M, Smida M, Chebbi A, Marzouk B, Tounsi MS. 2018. Effect of environmental conditions on the chemical composition and antioxidant activity of essential oils from Rosmarinus officinalis L. growing wild in Tunisia. J Essent Oil $\begin{array}{llll}\text { Bearing Plant } 21 & \text { (4): 972-986. DOI: }\end{array}$ 10.1080/0972060X.2018.1533433.

Zeggwagh NA, Ouahidi ML, Lemhadri A, Eddouks M. 2006. Study of hypoglycaemic and hypolipidemic effects of Inula viscosa L. aqueous extract in normal and diabetic rats. J Ethnopharmacol 8 (2): 223-227. DOI: 10.1016/j.jep.2006.05.005.

Zhao YM, Zhang ML, Shi QW, Kiyota H. 2006. Chemical constituents of plants from the Genus Inula. Chem Biodivers 3 (4): 371-384. DOI: $10.1002 /$ cbdv.200690041 